\title{
Chapter 3 Sceptical Motifs in The Kuzari
}

In this central section of the study, I will explore and explain Judah Halevi's use of motifs of the non-assent type of scepticism (i.e., the scepticism of the classical Hellenistic tradition) in his book. I will do so by engaging in a close reading and discussion of three sections of The Kuzari (I, 11-25; I, 67; V, 14) which, in my opinion, contain important examples of this kind of scepticism.

\section{A The Kuzari I, 11-25}

The dialogue in I, 11-25, which I will discuss below, is the introductory conversation between the Khazar king and the rabbi. The discussion between these two figures forms the bulk of The Kuzari, starting in I, 11 and going all the way to the end of the book. It is preceded by brief dialogues between the Khazar king and a philosopher (I, 1-4), the Khazar king and a Christian scholar (I, 4-5), and the Khazar king and a Muslim scholar (I, 5-10). As befits the beginning of an important dialogue, one that will last for the rest of the text, the introduction in I, 11-25 constitutes a vital move. In it, Halevi presents an initial and concentrated (though systematic) expression of his fideist approach. This is one of the most interesting and important moves not only in The Kuzari itself, but in medieval Jewish thought in general. Therefore, the assumption presented below - namely, that Halevi relies heavily on sceptical thought in formulating his opening move - may shine a new light on an important aspect of Halevi's thought.

Below, I will discuss the exchange between the Khazar king and the rabbi in I, 11-25, following the progression of the dialogue. Nonetheless, the discussion below is also selective, with the attention focused on those details that are relevant to the discussion of sceptical motifs. The starting point of the segment of dialogue in I, 1125 is the Khazar king's earlier request that his new interlocutor provide a dogmatic presentation of his religion. This question appears in the transition between the dialogues with the Muslim scholar and the Jewish rabbi: "He then summoned one of the Rabbis of the Jews and asked him about his belief (wa-sa'alahu 'an i'tiqaddihi)." The Arabic term i'tiqād ("belief"), based on the root '.q.d. like equivalent terms such as 'aqidah and mu'taqad, concerns the dogmatic presentation of the religion's core principles. ${ }^{1}$ The introductory question that Halevi places into the Khazar king's mouth implicitly relies on the assumption that the common method of identifying and understanding one religion in distinction to other religions is by means of a dogmatic definition, which was prevalent in Arabic culture from a relatively early stage of the development of Islam..$^{2}$ In the rationalist streams of this culture, espe-

\footnotetext{
1 See Frank, “Knowledge and Taqlīd," 42 n. 15. 
cially those of kalām, a dogmatic definition of a religion was one based on intellectual inquiry. ${ }^{3}$

The rabbi responds to the Khazar king's request for a dogmatic definition of his religion with the following words:

I have faith (anā mu'min) in the God of Abraham, Isaac, and Israel, who brought the children of Israel out of Egypt with signs and miracles, provided for them in the wilderness, and gave them the territory of the Levant ( $\operatorname{ard}$ al-šăm) after they had miraculously crossed the sea and the Jordan. He sent Moses with His Law, and then thousands of prophets after him to support His Law by means of promises [of reward] to whoever observed it and threats [of punishment] to whoever disobeyed it. Our faith pertains to all that was included in the Torah, but the report is long (wa-l-habar țawil). [I, 11]

Because the rabbi begins with the formulation "I have faith" (ana mu'min), it may be understood that what he is going to say next will include what he considers to be the credo of his religion. The presentation of Jewish belief here is based on an acceptance of the narrative of the biblical history of the people of Israel, a narrative that begins with the patriarchs and continues through the exodus from Egypt, the giving of the Torah through the mission of Moses, and the mission of the prophets who were faithful to it (whose estimated number here is far higher than the usual estimate in the Jewish tradition $)^{4}$ who succeeded him. The fact that the rabbi's definition of Judaism in I, 11 makes reference to events cited in the Bible shows that Halevi felt that it is the biblical narrative, rather than any dogmatic principles, that provides us with the definition of Judaism. And the definition provided by the Bible focuses on the relationship between God and His chosen: the patriarchs, the people of Israel, and the prophets.

From an epistemological point of view, the end of the rabbi's opening statement - "but the report is long" (wa-l-habr țawil) - is the key expression. He draws our attention to the fact that the epistemology of the concept of knowing, which underpins the rabbi's presentation of Judaism in I, 11 and the entire dialogue with the Khazar king in I, 11-25, is the traditionalist Muslim epistemology; that is, the doctrine regarding reports (habar, pl. ahbār). ${ }^{5}$ The formative development of early Islam

2 See Jon Hoover, “Creed,” in Encyclopaedia of Islam, THREE, ed. Kate Fleet, Gudrun Krämer, Denis Matringe, John Nawas, and Everett Rowson (consulted online on 06 February 2020. http://dx.doi. org/10.1163/1573-3912_ei3_COM_25587). The Christian scholar in I, 4 and the Muslim scholar in I, 5 have already provided the Khazar king with dogmatic descriptions of their religions.

3 Frank, "Knowledge and Taqlid," 44-45.

4 See Babylonian Talmud, Megillah 14a: "Forty-eight prophets and seven prophetesses prophesied to Israel."

5 See Arent Jan Wensinck, "Khabar," in Encyclopaedia of Islam, Second Edition, vol. 4, ed. Emeri van Donzel, Bernard Lewis, and Charles Pellat (Leiden: Brill, 1978), 895. See also Aron Zysow, The Economy of Certainty: An Introduction to the Typology of Islamic Legal Theory (Atlanta, GA: Lockwood Press, 2013), 7-8; Shady Hekmat Nasser, The Transmission of the Variant Readings of 
was extensively reliant on reports attributed to Muhammad, the prophet of Islam. These reports were passed orally through a chain of transmitters, the first of which consisted of the witness who was physically present at the event being reported. Such reports were the cornerstone that shaped the oral tradition of Islam: "the good example of the prophet" (sunnat al-nabi). ${ }^{6}$ The traditionalist concept of knowledge, at whose core lies the notion of the report (habar), differs from the rationalist one. The traditionalist concept emphasises the absolute commitment to reporting exactly what can be apprehended by the senses in the case of the witness who is the first link in the chain of the transmission of the report and absolute fidelity to the precise verbal contents of the orally transmitted report in the case of the subsequent transmitters. This fidelity to the contents of the report requires its transmitters to avoid inserting their own opinions and judgments into the process of transmission, including their own rational considerations. ${ }^{7}$ Significantly, the concept of traditionalist knowledge lacks the component of verification/assent (tașdiq) in its rationalist sense, in which the one who attains knowledge is required to verify it by means of the procedures and considerations of intellectual inquiry. ${ }^{8}$ In the context of the traditionalist concept of the transmission of reports, the evidence of the senses, transmitted orally at the highest level of transmission known as "concurrent transmission" (tawātur), ensures a certain and immediate knowledge, making assistance from intellectual inquiry redundant. ${ }^{9}$ Confirmation that the dialogue in I, 11-25 refers to the traditionalist epistemology is provided by the manner in which Halevi interweaves two terms that are typical of this approach into the rabbi's words: 'iyān, which relates to the direct perception of the eyewitness of the report in which he is the first link in the chain of transmission, and tawätur, which relates to the manner of the report's transmission at various other stages. In the traditionalist Muslim ap-

the Qur'ān: The Problem of Tawātur and the Emergence of Shawādhdh (Leiden: Brill, 2013), 65. On the traditionalist stream in Islam, see Binyamin Abrahamov, Islamic Theology: Traditionalism and Rationalism (Edinburgh: Edinburgh University Press, 1998), chapters 1-3.

6 Gautier H.A. Juynboll, "Sunna," in Encyclopaedia of Islam, Second Edition, vol. 9, ed. Clifford Edmund Bosworth, Emeri van Donzel, Wolfhart P. Heinrichs, and G. Lecomte (Leiden: Brill, 1997): 878-81.

7 Nasser, The Transmission of the Variant Readings of the Qur'ān, 68-69. Binyamin Abrahamov classifies the Muslim traditionalists who denied any involvement of rational considerations in the acquirement of religious knowledge as belonging to "pure traditionalism." See Abrahamov, Islamic Theology: Traditionalism and Rationalism, $\mathrm{x}$.

8 On tașdīq in the rationalistic frameworks of kalām and falsafah, see Damien Janos, "Al-Fārābī, Philosophy,” in Encyclopaedia of Islam, THREE, ed. Kate Fleet, Gudrun Krämer, John Nawan and Everett Rowson (consulted online on February 6, 2020. http://dx.doi.org/10.1163/1573-3912_ei3_COM_26962). Frank, "Knowledge and Taqlīd," 38-42. See also Jonathan A.C. Brown, Hadith: Muhammad's Legacy in the Medieval and Modern World (Richmond: Oneworld, 2009), 177.

9 Zysow, The Economy of Certainty, 14-15; Nasser, The Transmission of the Variant Readings of the Qur'ān, 69-70. 
proach, tawātur, as a process of transmission which relies on a large number of witnesses and many chains of transmission, absolutely ensures the reliability of the report. ${ }^{10}$ While "concurrent transmission" (tawātur) serves as a key term for the religious epistemological system as a whole in both the traditionalist Muslim approach and Halevi's approach, in the Muslim philosophical tradition, the role of this term is secondary, as it is restricted to the verification of specific empirical pieces of geographical and historical information and not to general universal truths. ${ }^{11}$

At the theological level, this epistemological approach is, for Muslim traditionalists, an alternative to the rationalist approach of kalām. While kalām scholars base the attributes of God on a rationalistic process centred on "inferences about the concealed from the manifest” (al-istidlāl bi-l-šâhid 'alā al-g்à'ib), traditionalist scholars base the attributes of God on reports going back to the prophet of Islam whose reliability is ensured by the oral process of "concurrent transmission" (taw $\bar{a}$ tur). ${ }^{12}$ Given all of this, the common assumption among many of the Muslim mutakallimūn scholars, sages of the kalām schools, that the knowledge acquired through human intellectual inquiry and the knowledge acquired through revelation and the transmission of tradition were congruent ${ }^{13}$ allowed them to assimilate the epistemology posited by the traditionalist scholars into their own method as a channel of cognition that matched the intellectual one. According to these kaläm scholars, the two channels together cement "necessary knowledge" ('ilm darūrì); that is, knowledge that is certain and binding from a rational perspective. This syntactic attitude was most conspicuously implemented by the mutakallimūn in the field of "principles of jurisprudence" (ușūl al-fiqh), as well as in the polemical genre of the "signs of prophecy" (a lām/dalā'il al-nubuwwah). ${ }^{14}$

This historical background regarding the essential gap between the traditionalist and rationalist epistemologies in Islam helps us to understand the Khazar king's disappointed reaction to how the rabbi presents the principles of Jewish belief:

10 See the diagram and explanations in Nasser, The Transmission of the Variant Readings of the Qur'ān, 67-70. See also Zysow, The Economy of Certainty, 7 ff.; Lobel, Between Mysticism and Philosophy, 220 n. 9.

11 Thus, we find that Ibn Sīnā treats "concurrent tradition" (tawātur) as a demonstrative proof of empirical truths that we have not witnessed ourselves (such as the existence of Mecca, Galen, and Euclid, in the examples provided by Ibn Sīnā). See Deborah L. Black, Logic and Aristotle's Rhetoric and Poetics in Medieval Arabic Philosophy (Leiden: Brill, 1990), 99; Black, "Epistemology in Philosophy," in Encyclopedia of Islam, THREE, ed. Kate Fleet, Gudrun Krämer, Denis Matringe, John Nawas, and Everett Rowson (consulted online on 06 February 2020. http://dx.doi.org/10.1163/ 1573-3912_ei3_COM_26198), sec. 4.

12 Abrahamov, Islamic Theology: Traditionalism and Rationalism, 34, 87 n. 19.

13 Abrahamov, 49-51.

14 See Nasser, The Transmission of the Variant Readings of the Qur'ān, 69-70 n. 136; 71-72 n. 138; David E. Sklare, Samuel Ben Hofni Gaon and His Cultural World: Texts and Studies (Leiden: Brill, 1996), 158, 161-62; Stroumsa, Freethinkers of Medieval Islam, 22-36. 
The Khazar said: I had originally decided not to ask a Jew because I knew about the destruction of their traditions and the inferiority of their opinions, since their misfortune has not left them anything worth praising. Why, then, didn't you say, O Jew, that you have faith in the Creator of the world, who orders it and governs it (wa-nāzimihi wa-mudabbirihi), and in Him who created you and provided for you, and [use] similar such descriptions, which constitute proof for everyone who has a religion (al-awșāf alatī hiya huğğat kull dī dīn)? Because of descriptions (awșāf) like these, people pursue truth and justice in order to imitate the Creator with reference to His wisdom and justice (li-l-tašabbuh bi-l-hāaliq fi hịkmatihi wa-'adlihi). [I, 12]

The Khazar king's disappointment with the rabbi's presentation of the Jewish faith in I, 11 stems from the fact that it is based not on any of God's universal descriptions or attributes ${ }^{15}$ that touch on His relationship with the universe as the one who created, orders, and governs the world, but rather on His particular attributes in a relationship with humanity's chosen. The Khazar king's assertion that the descriptions of God as the one who created, orders, and governs the world "constitute proof for everyone who has a religion” (al-awșāf alatī hiya ḥuğğat kull dī dīn) is indeed borne out by the earlier parts of The Kuzari. Both the Christian scholar and the Muslim sage introduce their religions to the Khazar king with descriptions that are, to a great extent, aligned with his claim about God's universal attributes. ${ }^{16}$ This is particularly evident in the Christian's credo:

[The Christian scholar] said to him: I have faith in the complete innovation of created things and in the eternity of the Creator, exalted be He. He created the world in its entirety in six days. [...] God has providential concern for creation, and contact with the rational beings (al-nātiqīin). $[\mathrm{I}, 4]$

The Khazar king's assertion regarding "proof for everyone who has a religion" is not only backed by the Christian and Muslim interlocutors in The Kuzari itself. The two most systematic and influential rabbinic theological works in Judeo-Arabic culture prior to Halevi's era - The Book of Beliefs and Opinions (Kitāb [al-Muhtār fi] alamānāt wa-l-i'tiqāāàt) by Sa'adia Gaon and The Book of Direction to the Duties of the Heart (Kitāb al-hidāyah ilā farā'ị̣ al-qulūb) by Bahya ibn Paqudah - also devote much space to depicting the principles of Judaism as being founded on the universal link between God and the world with God as the one who created, orders, and governs it. ${ }^{17}$ Therefore, the Khazar king's disappointment reflects a similar disap-

15 Compare the Khazar king's utterance regarding God's descriptions (awșāf) here (I, 12) with his utterance regarding God's attributes (șifät) at a later stage of this part of the dialogue between him the rabbi (I, 24).

16 I, 4 (8, ll. 23-26 = Bashir, 160); 5 (12, ll. 6-7 = Bashir, 164).

17 In the case of Sa'adia's The Book of Beliefs and Opinions, the whole work can be considered as a presentation of this kind (especially the first five of the work's ten parts). In the case of Bahya's The Guide to the Duties of the Heart, the first two parts (out of ten) can be considered as this kind of presentation. 
pointment that the typical readers of the book - the literates of the Judeo-Arabic culture - would surely also have experienced. ${ }^{18}$ Such learned people would have expected Halevi to present a description of Judaism whose introductory universal principles were close to those of Sa'adia Gaon, Bahya ibn Paqudah, and other dogmatic rationalist Jewish thinkers of that time. This expectation demonstrates that in the context of Arabic culture, the dogmatic discussions that writers put forth to explain their religions were close to and in the spirit of parallel discussion within the other religions of the same culture. Despite their differing religious loyalties, writers in this culture had much in common when it came to the manner in which they provided universal explanations for their different religions in the spirit of the dogmatic rationalist approach. ${ }^{19}$

The exchange between the rabbi and the Khazar king in I, 11-12 is a preface to the appearance of sceptical motifs in the discussion. From the Khazar king's reaction in I, 12, it is clear that the rabbi's presentation of Judaism in I, 11 falls outside the realm of understanding of those who, like the king, support the dogmatic rationalist attitude to religion. The rabbi's subsequent manoeuvres bring him into the orbit of rationalist discussion, which is critical in order to make a connection with the Khazar king's rationalist worldview. However, the rabbi shapes this manoeuvre not in accordance with the perspective of the common dogmatic approach, but rather from a perspective that is close to the sceptical version of rationalism:

The Rabbi said: What you are referring to is the syllogistic, governmental religion to which speculation leads (al-dīn al-qiyāsī al-siyāsī yu'addī ilayhi al-nazrr), but it contains many \{doubtful points\}. ${ }^{20}$ Ask the philosophers about it, and you will not find them agreeing on a single action or a single belief because they are [merely] claims. Some of them, they can demonstrate (yubarhinü' 'alayhā). Some of them, they can support persuasively (mā yuqni 'ūna fih $\bar{a}$ ); but

18 Written in Judeo-Arabic, works such as the above-mentioned ones by Sa'adia, Bahya, and Halevi were exclusively directed to a Jewish audience. At the same time, those authors made abundant use of terminology borrowed from the great variety of Arabic schools of thought in this era. This measure limited the intelligibility of their works (in their original language) to the small percentage of Jewish readers who had mastered Arabic and who were learned in the many facets of Arabic culture. See Eliyahu Ashtor, The Jews of Moslem Spain [Hebrew] (Jerusalem: Qiryat Sefer, 1966), 2:246-47, 300.

19 This phenomenon is clearly manifested in Abraham ibn 'Ezra's response to the question posed to him by Judah Halevi: "Why did [the Scripture] mention 'I am the Lord thy God, who brought thee out of the land of Egypt' rather than 'who made the heavens and the earth and you'?" Ibn 'Ezra's response to this key question displays the dogmatic rationalistic attitude to religion that was current among the Judeo-Arabic intelligentsia as well as among the like-minded Muslim intelligentsia (see the discussion later in this chapter).

20 The words inserted in curly brackets by the editors of the critical edition indicate places where the Oxford manuscript can be amended by other "text witnesses" such as the Medieval Hebrew translation. 
some of them they cannot even support persuasively (mā laysa yuqni 'unna fihā), let alone establish by demonstration (al-burhān). [I, 13]

The last words of the Khazar king in I, 12 - "people pursue truth and justice in order to imitate the Creator with reference to His wisdom and justice" - provide the rabbi with an opportunity to forge a link between the religion that relies (as the Khazar king says) on those issues that "constitute proof for everyone who has a religion" and the "syllogistic, governmental religion." This religion is yoked to the structural and planning interests of a socio-political body. A central source through which Halevi could have become familiar with this interpretation of religion is the writings of al-Fārābī and his and other writers' interpretations of Plato's doctrine of political philosophy. In the politico-philosophical thought of Abū Nașr al-Fārābī (Alfarabius, d. 950), known as "the Second Teacher" (al-mu'allim al-tāin̄) after Aristotle in the Arabic philosophical tradition and the father figure of the falsafah school, the imitation ideal is a political and religious one. According to al-Fārābī, the philosopher is simultaneously a legislator, a king, and the supreme religious leader (imām). As such, he is commanded to institute a political society whose orders, which he sets, are an imitation of God's: the one who orders and governs the world. In al-Fārābī's view, expressed in his The Opinions of the Citizens of the Virtuous City (Ārā' ahl almadīnah al-fädilah) and elsewhere, in the ideal regime where the philosopher-imām legislates and governs, the orders of the political society and the orders of religion are inextricably intertwined. Al-Fārābi sees the imām, the one whose perfect attributes make him capable of leading the perfect politico-religious order, as being eligible to govern the entire inhabited part of the world. ${ }^{21}$

This Arabic political philosophy, with its religious flavour as presented by alFārābī, had a considerable influence. Within Judeo-Arabic thought, the work of Maimonides was especially affected by this doctrine. ${ }^{22}$ Moses ibn Ezra (d. c. 1138), the noted poet and literatus who was the patron of the young Halevi, was familiar with al-Fārābì's above-mentioned work and cited it in his own work The Book of Conversation and Discussion (Kitāb al-Muhạạarah wa-l-mudākarah). ${ }^{23}$ In that text, he quoted passages from an essay attributed to Aristotle about a political vision of a world-state in which the universal uniform law affords inhabitants such peace and security that they are able to spend a great deal of time dealing with the ultimate

21 Abū Nașr al-Fārābī, Ārā' ahl al-madīnah al-fāḍilah, ed. Albert N. Nader, 7th ed. (Beirut: Dār alMašriq, 1996), 127 (wa-huwa al-ra'īs al-ummah al-fādilah wa-ra'īs al-ma'mūrah min al-arḍ).

22 See Lawrence V. Berman, “The Political Interpretation of the Maxim: The Purpose of Philosophy Is the Imitation of God," Studia Islamica 15 (1961): 53-61; Nadja Germann, “Al-Farabi's Philosophy of Society and Religion," in The Stanford Encyclopedia of Philosophy, Summer 2018 Edition, ed. Edward N. Zalta, https://plato.stanford.edu/entries/al-farabi-soc-rel/ (last visited 30.05.2019).

23 Moses Ibn Ezra, Kitāb al-muḥạdarah wa-l-mudāakarah, ed. and trans. Abraham Solomon Halkin (Jerusalem: Mekize Nirdamim, 1975), 108-9. 
purpose of wisdom. ${ }^{24}$ Ibn Ezra's innovative addition, as someone who favoured a political religion of this sort, is the identification of this philosophical vision of the ideal future political and religious order with the eschatological messianic visions of the biblical prophets. ${ }^{25}$

Halevi, who is opposed to the "the syllogistic, governmental religion," has the rabbi utter the classical sceptical claim regarding disagreements. In antiquity, Hellenistic sceptics applied this claim against the dogmatic philosophers to virtually every debate, regardless of the issue. Cicero, as the representative of Academic scepticism, makes great use of it in his polemic against his Stoic dogmatic rivals as a leitmotif in his speech in the Lucullus dialogue, ${ }^{26}$ while Pyrrhonian sceptics placed this assertion into a systematic framework as the "mode" related to "dispute" or "disagreement" (diaphōnia), the first of the five "modes" attributed to the sceptic Agrippa. ${ }^{27}$

In the context of Arabic culture, a discourse incorporating components stemming from scepticism generally tended to focus on the phenomenon of the disagreement among religions and their followers and the sceptical ramifications arising from this disagreement. ${ }^{28}$ In comparison, in the transition from I, 12 to I, 13, Halevi approaches the spirit of classical Hellenistic sceptical discourse when he shifts the weight of the argument related to dispute or disagreement from the religions to the philosophers. ${ }^{29}$ This shift in the debate's focus stems in part from the fact that Halevi has already mentioned the lack of agreement among religions earlier in the composition, in a section of the dialogue between the Khazar king and the philosopher:

The Khazar said to him: [...] Otherwise, [consider the fact] that the Christian and the Muslim, who have divided up the whole world between themselves, wage war against one another, although each of them has already directed his intention sincerely towards [pleasing] God. Each has taken up the monastic life. Each has practiced asceticism. \{Each\} has fasted and prayed. Yet each has gone off determined to kill his counterpart, believing that the greatest good and

24 Kitāb al-muhāạdarah wa-l-mudākarah, 270-71. See also Samuel M. Stern, Aristotle on the World State (Columbia: University of South Carolina Press, 1970), 79.

25 See Stern, 36, 84 n. 1.

26 See, for example, Cicero, On Academic Scepticism, 68-69, 72, 78, 83 (Lucullus, sec. 117-18, 124, 133, 143).

27 Diogenes Laertius, Pyrrhonian Skepticism in Diogenes Laertius, 33 (sec. 88); Sextus Empiricus, Outlines of Scepticism, 40-41 (I, 164-65). See also Jonathan Barnes, The Toils of Scepticism (Cambridge, University Press, 1990), 1-35.

28 Heck, Skepticism in Classical Islam, 15-16, 75, 79-81; Moshe Perlmann, "Ibn Ḥazm on the Equivalence of Proofs," Jewish Quarterly Review 40, no. 3 (1950): 279-90; Joel L. Kraemer, Humanism in the Renaissance of Islam: The Cultural Revival during the Buyid Age (Leiden: Brill, 1986), 15, 189-91. 29 For the Hellenistic sceptics' focus on the disagreement among philosophers in general, see Barnes, The Toils of Scepticism, 8 n. 8. For the claim of disagreement among philosophers in issues of religion, see Sextus Empiricus, Outlines of Scepticism, 200-201 (III, 218-19). 
[the best way to achieve] closeness to God lies in killing the other. And so, they are both killed, while each of them believes that his journey leads to the Garden [of Eden] and Paradise. But it is rationally impossible for both of them to be right (wa-tașdīquhumā muhāa 'ind al-'aql). [I, 2] The philosopher said: There is no killing of [either] one of these people according to the religion of the philosophers (dīn al-falāsifah), since they follow the intellect. [I, 3]

At the end of the Khazar king's words in I, 2, Halevi inserts the assertion that wars between the followers of the religions of revelation - Christianity and Islam, in this case - in the name of their respective religions are absurd when considered from a rationalist perspective. In response, the philosopher legitimises the Khazar king's argument, using the opportunity to point to the superiority of the "religion of the philosophers" over the others mentioned, as it avoids the absurdity of those other religions. The "religion of the philosophers" is here described as a religion whose unifying intellectual foundation is capable of preventing violence and bloodshed caused by loyalty to the religions of revelation such as Christianity and Islam. ${ }^{30}$ Now, if we return to the rabbi's words in I, 13, we can interpret the shift of attention to the lack of agreement among philosophers as a response to the philosopher's words in I, 3. The conclusion is that not only are the adherents of the revelatory religions unable to agree with one another, but also the philosophers, for whom the human intellect is the only beacon that is worth following, are incapable of agreement either on the general tenets of belief or on the specific commandments of their religion. In the view of philosophy under discussion, the "syllogistic, governmental religion," like all other "intellectual nomoi” (al-nawāmīs al-'aqliyyah), is tied in a Gordian knot to a political association: the primary factor in the use of organised violence. ${ }^{31}$ The ramifications of the disagreement among philosophers when it comes to both the generalities and the specifics of their religion on the possibility of violent clashes among societies based on a rational political religious order are clear (even though they are not spelt out here). In the absence of any such agreement among philosophers, they are incapable of establishing a uniform or compatible political order that can resolve the intractable problem of violent clashes between different politico-religious societies, the problem noted by the Khazar king in I, 2. The insertion of the classical sceptical assertion about disagreement among philosophers allows Halevi to point to the false pretention embedded in the philosopher's words in I, 3. Indirectly, however, the use of the assertion here serves to point out

30 For the background of this claim in the legacy of the so-called freethinkers of the classical Islamic period, see Sarah Stroumsa, "Prophecy versus Civil Religion in Medieval Jewish Philosophy: The Cases of Judah Halevi and Maimonides," in Tribute to Michael: Studies in Jewish and Muslim Thought Presented to Professor Michael Schwartz, ed. Sara Klein-Braslavy, Binyamin Abrahamov, and Joseph Sadan (Tel-Aviv: Tel-Aviv University, 2009): $89^{\star}-93^{\star}$.

31 See I, 80-81. Compare Ihwān al-Ṣafā', The Case of the Animals versus Man Before the King of the Jinn: An Arabic Critical Edition and English Translation of Epistle 22, ed. and trans. Lenn. E. Goodman and Richard McGregor (Oxford: Oxford University Press, 2009), 262-66 (Arabic), 301-6 (English). 
the delusional dimension inherent in the vision of world peace that Moses ibn Ezra cites in Aristotle's name as a vision relying on a uniform consensual politico-intellectual order. The inability of intellectual inquiry to establish such an order is reflected in the inability of philosophers - charged with a dogmatic rationalist approach - to reach an agreement on the components of the "syllogistic, governmental religion."

Moreover, the second part of the statement that Halevi has the rabbi say in I, 13 is evidence of the limitations of the sceptical discourse in his thought. Here, the rabbi is revealed as someone who does not favour scepticism in all things. Unlike the Hellenistic sceptics, he does not question the capacity of philosophical logic to prove demonstratively certain claims. Yet in the statement voiced by the rabbi in I, 13, Halevi, focusing on the issue of "the syllogistic, governmental religion," claims that the philosophers' disagreement on the matter is a consequence of their inability to base this religion solely on proofs of the demonstrative order, hence their need to also establish it on proofs of the dialectical order as well as on the lessermost proofs of the sophistic and rhetorical orders. The rabbi's argumentation here is strictly rational and philosophical, ${ }^{32}$ yet behind it lurks a fideistic orientation. As we have seen in the previous chapter, in Halevi's fideistic approach, the philosophers' failure is inherent because of the limitations of the human intellect. Their inability to achieve an agreement regarding the rules of religion that is based on demonstrative proof is a direct outcome of the fact that this matter lies outside the scope of "human wisdom" (al-hikmah al-insāniyyah), belonging instead to the realm of "divine wisdom" (al-hikmah al-ilāhiyyah). Consequently, their inability to agree on the actions of a religion is a direct outcome of the fact that many of these actions belong to the sphere of "the divine commandments known through revelation alone" (alšarā' $i^{\prime}$ al-ilāhiyyah al-sam'iyyah), which also lie outside the scope of intellectual considerations.

The positive tone of the Khazar king's subsequent response (I, 14) to the rabbi's comments in I, 13 is conspicuous given the intensely negative tone that marked his previous response (in I, 12) to the rabbi's opening statement in I, 11:

The Khazar said: I think your speech now, O Jew, is more likely [to persuade me] than the opening part of it was before, and I would like additional proof. [I, 14]

The basis for this more appreciative response lies in the fact that in I, 13, the rabbi moved the debate onto a rationalist track. The Khazar king identifies the generally

32 See the discussion in Ariel Malachi, “'On The Soul’ by Ibn Sina: A Remark to the Hebrew Translation and Its Implication for Yehuda Halevi” [Hebrew], Da'at 81 (2016): 111-21. See also Harry A. Wolfson, Crescas' Critique of Aristotle: Problems of Aristotle's Physics in Jewish and Arabic Philosophy (Cambridge, MA: Harvard University Press, 1929), 397; Barry S. Kogan, "Judah Halevi and His Use of Philosophy in the Kuzari,” in The Cambridge Companion to Medieval Jewish Philosophy, 118. 
rationalist tone of the rabbi's words and connects with it. The rationalism that the rabbi presents in 1, 13, although it is a rationalism that involves a sceptical argument, sounds just familiar enough for the Khazar king to overcome his previous reservations and awaken his interest in the rabbi's course of argumentation.

The rabbi's next words mark another turning point. Throughout the dialogue in I, 11-25, the rabbi's general orientation is not to gratify the Khazar king by demonstrating a proclivity for rationalist discourse, but rather to challenge him by confronting him with a definition of Judaism that is contrary to the way in which rationalist writers would tend to define it. Accordingly, the rabbi now acts to steer the debate away from the rationalist direction:

The Rabbi said: On the contrary, the opening part of my speech is the demonstration (alburhān). What is more, it is [based on] eyewitness perception (al-'iyān) and doesn't need proof and demonstration (dalīl wa-burhān). [I, 15]

In this brief passage, Halevi juxtaposes and contrasts the two epistemological tracks through which he conducts the debate in I, 11-25, the main track being that of the traditionalist Muslim epistemology based on the testimony recorded by the senses and thereafter transmitted through a chain of transmission. The term 'iyān ("eyewitness perception") is the key term of this epistemology which touches on this side of the initial stage of sensory input. In addition, the rabbi makes two references to the term burhān. These references are based on the dual significance of burhān in Arabic literature in general and in Judeo-Arabic literature in particular: in the rationalist, philosophical track, the term burhān denotes the level of "demonstrative proof," the highest and most certain order of rational proofs. ${ }^{33}$ In the other track, that of the translated literature and the Judeo-Arabic interpretations of the biblical text, such as in the writings of Sa'adia Gaon, burhān is the Arabic term parallel to the biblical divine "sign" (Heb. mofet) in the sense of a miraculous event perceived by the senses. In Sa'adia Gaon's thought, the two meanings of burhān join together as part of a dogmatic rationalist approach that Harry Wolfson called the "double faith theory": ${ }^{34}$ the concrete miraculous "sign" is intended to strengthen belief in the principles of the religion given to a prophet through divine revelation, though these principles are also validated through intellectual inquiry. However, in Halevi's thought, as someone taking a fideist approach, the relationship between the two meanings of burhān takes a completely different form: burhān, as a sign of a concrete miracle

\footnotetext{
33 The rabbi refers to this meaning of the term burhān in the second half of his previous comment (I, 13).

34 Harry A. Wolfson, "The Double Faith Theory in Clement, Saadia, Averroes and St. Thomas, and Its Origin in Aristotle and the Stoics," The Jewish Quarterly Review 33, no. 2 (1942): 230-43. For the shift in the meaning of the term burhān from its Qur'ānic denotation as a miraculous sign to its philosophical sense of "demonstrative proof," see Mark N. Swanson, "Proof," in Encyclopedia of Quran, ed. Jane Dammen McAuliffe (Leiden: Brill, 2004), 4:286-87.
} 
perceived by those who were present, who experienced it as a direct sensory occurrence, removes those witnesses' complementary need for burhān as a certain logical proof: the highest achievement of intellectual inquiry. In a manner that is typical of his fideist approach, in the context of the credo of the Jewish faith - that is, the miraculous revelatory events of the people of Israel - Halevi grades cognition based on direct sensory eyewitness perception ('iyān) far above cognition based on intellectual inquiry. Furthermore, the rabbi's words in 1, 15 are a refinement of what he said in the second half of 1,13 . The earlier passage created the impression that the philosophers' problem in formulating their religion is based on the fact that philosophers are incapable of validating the entirety of their religion by means of the highest order of proof, that of demonstrative proof (burhān). The rabbi's words in I, 15 now come to clarify that when it comes to the credo of the Jewish faith - a credo relying on direct sense perception - intellectual proofs, even of the demonstrative order, are unnecessary. ${ }^{35}$

The following brief exchange between the Khazar king and the rabbi functions as a transition which moves the discussion to the next stage:

The Khazar said: How is that possible? [I, 16]

The Rabbi said: Permit me to make some preliminary comments, because I see that you are showing disdain for my statements and making light of them. [I, 17]

The Khazar said: Make your preliminary comments so that I may hear [them]. [I, 18]

The rabbi's feeling, which he expresses in I, 17, that the Khazar king is scorning what he said in I, 15 is the result of his assessment based on his experience with the Khazar king's response to I, 11; namely, that the Khazar king cannot tolerate the rabbi's statements when they deviate from rationalist discourse. This comment precedes and hints at the fact that the rabbi is putting the discussion back onto the rationalist track, a move which he explains this time by means of a parable:

The sage said: If you were told that the ruler of India is a virtuous ruler, whom you should revere, whose name you should praise, and whose signs (ätārihi) you should recount because

35 Consider the rabbi's assertion at the end of I, 25: "I answered you in terms of what is compelling for me and for the community of the children of Israel for whom that [which I have described] is well-established on the basis of eyewitness perception (al-iyān) and, subsequently, through concurrent tradition (al-tawätur), which is as valid as eyewitness perception (ka-l-iyān)." From this assertion, we learn that eyewitness perception (al-iyān) must be completed by concurrent tradition (al-tawātur). Herein lies a fundamental difference between the traditional and rational-philosophical epistemological systems. Whereas in the traditional system, concurrent tradition (al-tawātur) serves as the complementary procedure for direct sense perception, in the rational-philosophical system, conceptualisation (tașawwur) and verification/assent (tașdìq) function as complementary procedures for sense perception. In relying on direct sense experience here, Halevi, like the traditionalists, avoids the procedures of conceptualisation (tașawwur) and verification/assent (tașdīq). See Black, "Epistemology in Philosophy," sec. 2. 
of what had come to your attention about the justice ('adl) of the people of his country, [signifying] both the excellence ( $f a d l)$ of their character traits and the justice ('adl) of their conduct towards one another, would this oblige you [to obey him] (hal kāna had̄ā yulzimuka)? [I, 19]

The words spoken by the rabbi in I, 15 were meant to create the impression that intellectual proof of the demonstrative order (burhān) is unnecessary for the concrete, observable, non-intellectual definition of Judaism, whereas in the next exchange with the Khazar king (I, 19-20), Halevi returns the discussion to the rationalist track to show that providing demonstrative proofs is beyond the ability of those who claim to base their belief on intellectual inquiry. To do so, he focuses the discussion in these lines on the proof that was most common and best known in dogmatic rationalist discourse in the reservoir of proofs for the existence of God. Historically, this claim did in fact constitute the "proof for everyone who has a religion" that the Khazar king had in mind in I, 12, and it was used by a very wide spectrum of rationalists in this and other periods. ${ }^{36}$ The popularity of the argument under discussion and the widespread distribution it achieved forced Halevi to be especially careful in presenting his own critical appraisal of it. We therefore find him discussing it by means of a parable whose meaning is not spelt out. However, the reference is not to anything esoteric; any intellectual of that time would immediately have grasped what the parable was trying to communicate. ${ }^{37}$

The intellectual proof manoeuver at the basis of the parable of the king of India in I, 19 is the one known in philosophical literature as the "argument from design" or the teleological argument. In the list of attributes the Khazar king ascribes to God in I, 12, the teleological argument relates to God being the one who designs and governs the world (wa-nazimihi wa-mudabbirihi). This argument is based on the claim that the contemplation of the world and its intricacy impresses the observer with the signs of design, coordination, and sophistication inherent in reality and the rela-

36 Binyamin Abrahamov, “Al-Ḳāsim ibn Ibrāhīm’s Argument from Design,” Oriens 29/30 (1986): 266-77; Diana Lobel, A Sufi-Jewish Dialogue: Philosophy and Mysticism in Bahya ibn Paquda's "Duties of the Heart" (Philadelphia: University of Pennsylvania Press, 2007), 117-45.

37 Throughout The Kuzari, Halevi takes a discreet attitude, not an esoteric one. He does not wish to conceal his positions, yet he chooses to take some discreet measures in order to avoid a head-on clash with the dogmatic rationalist positions deeply rooted in the minds of his associates and colleagues in the Judeo-Arabic intelligentsia. In the specific case of I, 19-21, the discreet attitude is achieved by the omission of the referent part of the parable. In a wider context, The Kuzari's historicisation, locating the plot of the work far away in both place and time, in the land of Khazaria during the eighth century, functions as another means of achieving the same purpose. This discreet attitude was part and parcel of the rules of the courtesy ( $a \mathrm{~d} \bar{a} b$ ) that was typical of Arabic culture, where people who belong to the same milieu avoid criticising each other in a confrontational manner. For another example of Halevi's discreet attitude, see the discussion of his use of the figure of Socrates in V, 14 below. 
tionships and compositions of all its existents. ${ }^{38}$ This insight leads to the conclusion that there is an external higher entity that dictates, directs, and preserves the order of reality. In the monotheistic versions of this proof, this external higher entity is identified with the one God of the monotheistic religions. The argument and its many forms constituted an important link connecting ancient Hellenistic philosophy with the thought of the church fathers and Muslim, Christian, and Jewish thought in Arabic culture. ${ }^{39}$

Addressing the parable in I, 19, relating to its meaning level that is left non-explicit by the author, the ruler of India hints at God, the land of India hints at the world in general, the people of India are the existents in the world, the justice (' $a d l$ ) and excellence $(f a d l)$ of the people of India hint at the well-planned order of the world's existents that arranges their actions, and the ruler's signs (ātārihi) by which the justice and excellence of his subjects are known stand for the explicit signs of the divine intelligent design in the world available for contemplation by humans. Based on such a contemplation or observation, all human beings can use their minds to acknowledge God as the initiator and preserver of the design of the world's existents. ${ }^{40}$

The question the rabbi poses to the Khazar king at the end of the parable "would this oblige you?” (hal kāna hadā yulzimuka) - is short for "would this oblige you to obey him?"; namely, the ruler of India in the parable and God in the referent. This is inferred from a comparison with the full parallel formulation of the concluding question in I, 21: "Would you be obligated to obey him?" (hal kunta taltazimu $t \bar{a}^{\prime}$ atahu). The fact that the discussion between the rabbi and the Khazar king in I, 19-21 concentrates on a parable whose non-explicit referent is the teleological argument for the existence of God does not only stem from this proof being the most commonplace in the rationalist discourse of the time, as The Kuzari contains other rationalist arguments for the existence of God: in I, 1, the philosopher mentions the cosmological argument, which concerns God as the first cause in the causal order of existence. ${ }^{41}$ The rabbi hints at Ibn Sīnā's ontological argument in IV, $25,{ }^{42}$ and in V,

38 In Arabic literature, there are two synonymous terms commonly used to describe this mode of rationalistic contemplation: i tibār and tafakkur. See Warren Zev Harvey, “Averroes and Maimonides in the Obligation of Philosophic Contemplation (i tibār)” [Hebrew], Tarbiz 58, no. 1 (1988): 75-83; Lobel, A Sufi-Jewish Dialogue, $120 \mathrm{ff}$.

39 Herbert A. Davidson, Proofs for Eternity, Creation and the Existence of God in Medieval Islamic and Jewish Philosophy (New York: Oxford University Press, 1987), 213-36.

40 Halevi may be hinting here at the first two parts of Bahya ibn Paqudah's The Guide to the Duties of the Heart, where the author constantly refers to the "argument from design" as an argument which relies on one's intellectual ability to contemplate "the signs of [divine] wisdom" (ātârr alhikmah) in the world.

41 I, 1 (4, 1l. 8-12 = Bashir, 154).

42 IV, 25 (278, 1. 27-280, 1. 3 = Bashir, 495). 
18, he spells out the argument from the creation of the world. ${ }^{43}$ However, none of these proofs stresses God's involvement in the existence of the world found in the argument referenced in the parable in I, 19. Therefore, the teleological argument, more so than the others mentioned, is what seemingly provides a stable intellectual foundation for the obligation to accept God's dominion and worship Him.

The Khazar king's reply to the question the rabbi posed at the end of I, 19 brings the reader into the very heart of the sceptical manoeuvre in the discussion in the dialogue of I, 11-25:

The Khazar said: How would it compel me, when there is doubt (wa-l-šakk) as to whether the justice of India's people ('adluhum) derives from themselves and they have no king, or [whether in having one,] their justice ('adluhum) is due to their king, or [whether] the fact derives from both causes taken together? [I, 20]

The key word in the parable of the ruler of India is the word "justice" ('adl). It appears twice in both the rabbi's initial presentation in I, 19 and in the Khazar king's response in I, 20. The word, which relates to the justice prevailing in all Indian affairs, is seen at the level of the (implicit) moral as referring to the design and order that characterises the world and its existents from which one may infer the existence of the divine designer. The assertion that Halevi has the Khazar king voice in I, 20 revolves around this term. The cause of this "justice" - that is, the design characterising the existents of this world - could perhaps be the world's existents themselves (the people of India in the parable), or God (the king in the parable), or the existents and God together. Thus, according to the Khazar king's assertion, the argument from design - that is, the claim that the order among the world's existents is the result of God's organising and steering hand - is in fact only one of three possible ways to make logical inferences as to the existence of such a design. The three possibilities are presented in the Khazar king's words here as three possible alternatives whereby none of the three seems to supersede or outweigh the others. The doubt (wa-l-šakk) that the Khazar king casts on the rabbi's explanation of the world's design here results from his arrival at two other equally compelling explanations of the same phenomenon. This non-assent set-up fits the basic set-up of claims in Hellenistic sceptical thought called the "equipollence of counter-arguments" (isostheneia). During the Hellenistic period, the teleological proof was especially prevalent among the Stoic thinkers. In response to the Stoics' assertion that observing the world requires the observer to recognise God or divine thought as the primary mover of the design of nature, the sceptics quoted other Hellenistic thinkers who claimed that the design perceived in the world is the result of the harmonious relationships among the world's existents. From the sceptics' viewpoint, this form

$43 \mathrm{~V}, 18(332,1.7-334,1.7$ = Bashir, 542-44). 
of arguing makes it clear that the claims are equivalent in weight. ${ }^{44}$ Compared to this classical sceptical discussion, in Halevi's writing, the weight of the teleological argument and its presentation in the parable goes from the intellectual aspect of proving the existence of God to the normative aspect of the obligation to obey God and accept His dominion. Against this background, we can understand the addition of the third combined possibility. From a viewpoint focused on proving the existence of God, which preoccupied the sceptics in their debates with the Stoics, the first two possibilities that the Khazar king mentioned in I, 20 distil the issue into a binary choice: the argument from design either can or cannot prove the existence of God as the one who designed it. By contrast, in Halevi's viewpoint here, the third combined possibility the Khazar king offers also has its place, because the combination weakens the aspect of God's sovereignty over the world and its existents, thereby raising questions about the obligation to obey Him. This shift of emphasis in the sceptical set-up of the argument from order is what enables Halevi to present three equally weighted options for this subject in comparison to Cicero's two.

From another comparative historical direction, one should note that in Hellenistic culture, global sceptical thought had its niche as a recognised philosophical tradition and was an integral part of that culture. The sceptical questioning of the teleological argument reported in Cicero's writings is unavoidable and is consequent to its position as a niche of global scepticism. Compared to this, in Arabic culture - a world that lacked a tradition of global scepticism, on the one hand, and in which the teleological argument represented a rare consensus, on the other - the implied sceptical critique Halevi levels against this proof is highly unusual and daring. ${ }^{45}$

The sceptical manoeuvre in I, 20 includes the central classical sceptical claim of the "equipollence of counter-arguments" (isostheneia). ${ }^{46}$ In this passage, the purpose of this sceptical assertion is to expose the pretensions to certainty in the teleological argument for the existence of God and the obligation to obey Him. The assertion in the Khazar king's statement that the indecision among the various claims, which are neither complementary nor matching when it comes to the argument from design, precludes the attribution of certainty to the proof of God's existence and the obligation to obey Him. In a historical context, it seems that Halevi's polem-

44 Cicero, On Academic Scepticism, 70-71, 74 (Lucullus, sec. 120-21, 126); Cicero, On the Nature of the Gods (De natura deorum), in On the Nature of the Gods. Academics, trans. Harris Rackham (Cambridge, MA: Harvard University Press, 1933), 124-27 (II, 2), 308-9 (III, 9-10), 312-13 (III, 11).

45 See Davidson, Proofs for Eternity, 216 and n. 21. According to Davidson, among all the medieval Islamic and Jewish literary sources that he checked, The Kuzari I, 20 contains the only criticism of the teleological argument.

46 Supportive evidence for my claim that the Khazar king's concise remarks in I, 20 contain the sceptical argument of the "equipollence of counter-arguments" can be found in I, 67, where Halevi explicitly articulates this argument. See the discussion below. 
ical sting in this sceptical manoeuvre was particularly aimed against his elder contemporary, Bahya ibn Paqudah. ${ }^{47}$

A comparison between the use of the "disagreement" (diaphōnia) sceptical argument in I, 13 and the use of another one, the "equipollence of counter-arguments" (isostheneia) in I, 20, reveals that while the former is voiced by the rabbi, the latter is voiced by the Khazar king. This is of great significance. In I, 20, the use of the sceptical argument is a sort of self-liberating development. The Khazar king, in speaking as he does, extricates himself from the grasp of dogmatic thought that characterised his approach when he first embarked on the dialogue with his Jewish interlocutor in I, 12. The placement of the sceptical position in terms of its validity and the binding nature of "the argument from design" in the Khazar king's speech is a successful demonstration of the emancipatory quality inherent in the sceptics' manner of argumentation. This quality is embedded in the argument's capacity to open the mind's field of vision in several directions. This opening is characteristic of sceptical thought, a development that frees its thinker from the hold of a reductionist tendency towards only one direction that is characteristic of the dogmatic approach. ${ }^{48}$ The Khazar king's words in I, 20 are a fine example of the emancipatory strength of classical scepticism. He abandons the dogmatic rationalism which reduces him to thinking that in every matter, there is one single assertion that may exclusively be considered to be certain. He exchanges this reductionist rational thought for sceptical rationalist thought, which recognises disparate or even contradictory arguments as striving for the truth without taking the reductionist step of trying to decide between them. This point also embodies the essential difference between Halevi's fideist thought and the rationalist approach characterising the classical sceptic. For the latter, remaining with disparate claims and examining them is his permanent intellectual state of being, the state of the sceptical "suspension of judgment” (epochē). By contrast, in the dialogue in I, 11-25, the Khazar king's tran-

47 As already hinted above, Halevi's focus on the argument from design can be seen as a response to the most serious theological product of his own Jewish-Andalusian milieu: Bahya ibn Paqudah's The Book of Direction to the Duties of the Heart. While in Sa'adia Gaon's work, the focus is still on the argument from creation, in Bahya's work, we find the centre of gravity shifting towards the argument from design. Furthermore, the issue of the connection between the contemplation ( $i$ 'tibār) of God's "signs of wisdom" (ätâr al-ḥikmah) in the world which points to Him as the supreme designer and the obligation to obey Him (iltizām ță'at Allah) is central to the discussion in parts 2 and 3 of Bahyah's work, as well as to Halevi's dialogue in I, 19-21. For the suggestion that Maimonides's parable about the small, weak moneychanger and the big, strong, impoverished individual standing before him (in Dalālat al-ḥā'irīn, ed. Solomon Munk and Isaschar Joel [Jerusalem: Y. Yunovits, 1929], I, 46) functions as a sort of counterblast to the parables in The Kuzari I, 19-21, see Shlomo Pines, “Translator's Introduction," cxxxiii.

48 On the non-reductionist approach as the approach of the sceptics, who favour several directions, vis-à-vis the reductionist approach of the dogmatists, who seek one direction, see Cicero, On Academic Scepticism, 6 (Lucullus, sec. 8). 
sition from dogmatic rationalism to sceptical rationalism is viewed as a desirable intermediate step en route to the readers' liberation from the need to define their Jewish beliefs in rationalist terms altogether. This fact, which characterises Halevi's approach at this point, is elucidated in the following lines of dialogue:

The Rabbi said: But then, if his messenger came to you with [typically] Indian gifts, about which you have no doubt (lā tašukku) that they are found only in India, in the palaces of kings, along with a message in which it is attested that it is from him [i.e., the king] and accompanied by medicines that cure you of your illnesses and preserve your health, as well as poisons for your enemies and those who wage war against you, with which you may confront them and kill them without preparation or [adequate] number [of soldiers], would you be obligated to obey him (hal kunta taltazimu țā'atahu)? [I, 21]

The rabbi does not respond to the sceptical exposition of the argument from design expressed by the Khazar king in I, 20. Instead, in I, 21, he presents another parable. The lack of response may indicate the rabbi's silent agreement with the Khazar king and that the rabbi considers the Khazar king's exposition to be appropriate. At the same time, in the transition to the parable in I, 21, Halevi parts ways with classical scepticism. He overlooks the stage of "suspension of judgment" in favour of continuing to develop the manoeuver whose starting point is the credo that the rabbi formulated in his introduction in I, 11. The rabbi's words in I, 21 are a reframing of the credo in I, 11 in the form of a parable. The unstated referent of the parable in I, 21 is closely tied to the assumptions underlying that credo: that the impressions of God on which it is necessary to base and accept His dominion are not the impressions of nature's design or other designs pointing to a God leading the world as a whole, but rather the impressions of God's involvement as manifested in the unique history of the people of Israel. The hypothetical experiences that could occur to the Khazar king according to the parable's literary descriptions in I, 21 are the real events experienced by the people of Israel during the biblical era according to the historical descriptions in I, 11 and elsewhere in The Kuzari. ${ }^{49}$

Furthermore, the capacity of the parable in I, 21 to move and persuade relies on the expressive, concrete descriptions that characterise it. The parable is a good example of the fact that to Halevi's mind, the power of a parable lies in its concrete rather than its allegorical nature. His omission of the allegorical aspect of the parable's lessons in both I, 19 and I, 21 is therefore an advantage. This omission stresses that the parable's persuasive advantage lies in the concrete aspect of this genre and dovetails with the definition of Judaism that the rabbi presented in I, 11 as a definition based on the concrete rather than the abstract. The parable in I, 21 echoes the definition of Judaism provided in I, 11: what instils awe of God and acceptance of

49 See, for example, I, 109. 
His word is direct experiences of His presence in history and the added value of the benefits conferred on those who participated in those experiences..$^{50}$

In these brief concrete parables, Halevi positioned two alternate options for defining Judaism and its binding validity: the dogmatic rationalist option of intellectual observation and inquiry and the historic option based on direct experience of the unique events that occurred to the people of Israel. The Khazar king's response in I, 22 reflects progress away from the sceptical stance of non-assent in which he placed himself in I, 20, moving towards the stance of the believing man, a position requiring an assent, according to Halevi's non-sceptical approach:

The Khazar said: Yes, of course. My previous doubt (al-šakk al-qadim) as to whether India has a king or not would have vanished, and I would believe (wa-kuntu a'taqidu) that his dominion and his imperative (mulkahu wa-amraru) extend to me. [I, 22]

The Khazar king's response here clearly demonstrates that the discussion, at the level of the parable of the argument from design, is encompassing two matters. The first is proving the existence of God, presented in the parable by the question of whether India has a king or not. The second is the submission of oneself to God's authority, which is presented in the parable with the statement "his dominion and his imperative (mulkahu wa-amraru) extend to me." As I explained earlier, in the context of Judeo-Arabic literature, the link between these two matters was expressed most forcefully in the opening rational-oriented parts of Bahya ibn Paqudah's work. ${ }^{51}$

The Khazar king's words in I, 22 represent the closing of a circle and his confirmation of the claim that the rabbi presented to him in I, 15. His sceptical response to the argument from design that the rabbi presented in I, 19 led him to the exposition of the "equipollence of counter-arguments" in I, 20, an exposition that contains doubt regarding the definition and binding nature of a religion that relies on an argument of this sort. By contrast, the Khazar king's response to the argument based on the direct historical sense evidence that the rabbi presents to him in the parable

50 Elsewhere, in IV, 13, Halevi stresses that seeking non-theoretical concrete material benefits distinguishes the adherent of a revealed Law from the adherents of philosophy: "The difference between the adherent of a revealed Law and the adherent of philosophy is far-reaching because the adherent of a revealed Law seeks out the Lord for the sake of great benefits, quite apart from the benefit of knowing Him. But the person who devotes himself to philosophy seeks Him out only for the purpose of describing Him according to His true character” (252, 11. 18-20 = Bashir, 464).

51 In my forthcoming study on Bahya and Halevi as radical thinkers, I will demonstrate at length that while the first three parts of Bahya's The Book of Direction to the Duties of the Heart (Kitäb alhidāyah ilā farā'id al-qulūb) encapsulate the non-radical rationalistic directions of his thought, the other seven parts present a radical Șūfi-oriented direction which constitutes his major contribution to Judeo-Arabic literature. 
in I, 21 removes the doubt and leads him to accept both God's existence and the yoke of His revealed religion.

The transition to the next exchange between the Khazar king and the rabbi in I, 23-24 focuses the discussion on the attributes of God. The rabbi steers the discussion to this topic by means of the question he poses to the Khazar king in I, 23. In his introduction to the dialogue with the rabbi, the Khazar king uses the more general phrase "descriptions" (al-awșāf) when referring to "descriptions, which constitute proof for everyone who has a religion" (I, 12). However, in the present and more advanced stage of the discussion between them, he uses the accepted technical term in the literature of Arabic culture - that of "attributes" (șifät): ${ }^{52}$

The Rabbi said: If you were asked about him, how would you describe him? [I, 23]

The Khazar said: By means of those attributes (bi-l-șifāt) that, in my opinion, were well-established on the basis of direct eyewitness perception ('iyānan). Then I would follow them up with those that were doubtful (mašku $k a)^{53}$ for me and have become evident by means of these last ones. [I, 24]

The attributes (al-șifāt) of God that the Khazar king refers to in I, 24 as being validated by "direct eyewitness perception" ('iyānan) - that is, by the direct evidence of the senses - are the attributes of God's sovereignty in His unique relationship with the people of Israel, its patriarchs, and its prophets. These attributes were noted by the rabbi in his credo in I, 11 - "the God of Abraham, Isaac, and Israel" - and all that was added to this description there, whereas the doubtful attributes (maškūkah) are the descriptions of God's sovereignty over the world and its existents, the same descriptions of the religion based on the dogmatic rationalist approach mentioned by the king in his first response to the rabbi's credo in I, 12 ("you have faith in the Creator of the world, who orders it and governs it, and in Him who created you and provided for you, and [use] similar such descriptions"). In I, 24, the Khazar king reaches a stage where he can acknowledge the primacy and superiority of the unique attributes of God, which, epistemologically speaking, rely on direct eyewitness perception ('iyānan), compared to God's general-universal attributes,

52 See Claude Gilliot, "Attributes of God," in Encyclopaedia of Islam, THREE, ed. Kate Fleet, Gudrun Krämer, Denis Matringe, John Nawas, and Everett Rowson (consulted online on 06 February 2020. http://dx.doi.org/10.1163/1573-3912_ei3_COM_0163).

53 The text of the Baneth-Ben-Shammai edition reads (11 and n. 18, 3) mašhūrah ("famous," "generally accepted") here. Herschfeld, in his edition, reads maškūkah ("doubtful”) in accordance with Ibn Tibbon's medieval Hebrew translation (hayu safeq eșli). The context shows that Ibn Tibbon's version is the correct one: in his two previous utterances, in I, 20 and I, 22, the Khazar king referred to his doubt ("when there is doubt" [wa-l-šakk] and "my previous doubt" [al-šakk al-qadìm] respectively) in relation to the attributes of the people of India and their king on the allegorical level of the fable. In I, 24, he refers to the same subject (i.e., God's attributes in His relation to the world). 
which have no verification by means of direct sense impressions. Furthermore, he now considers the first kind of attributes to be the basis for the validity of the second kind. This argument is only hinted at in I, 24; it receives detailed elucidation later in the book, especially in the rabbi's words in II, 54. There, the validation is learned from an observation of history: the first historical era, which preceded the emergence of the people of Israel, was characterised by the flawed and failed intellectual attempts on the part of all groups and schools of thought (including the philosophers) to reach a true acknowledgement of God's attributes and His governance of the world. ${ }^{54}$ The change occurred with the emergence of the people of Israel onto history's stage. The unique history of the people of Israel, whose striking events involved miracles and manifest changes to the natural order of things, was the reason why the "entire inhabited world" began to correctly acknowledge God's general-universal attributes and how the way in which He governs the world became known to all. ${ }^{55}$ Thus, Halevi's claim, presented in full in II, 54, is that the different religions and groups attained the correct understanding of God's attributes and His governance of the world not by taking any intellectual measures, but by surrendering themselves to the lessons of the unique history of the people of Israel.

The most interesting and important point in the context of our discussion relates to the fact that the Khazar king's conclusion in I, 24 regarding the verification of God's general-universal attributes based on His particular attributes was made possible because of a move he made earlier, in I, 20, which expresses his shift from dogmatic to sceptical rationalism. The dogmatic rationalist approach, which requires deciding among contradictory arguments on any given issue, entails two implications. The first is the validation of one of the arguments. The second is the refutation of all the other arguments, thus bringing the discussion of the issue to its conclusion. In contradistinction, in classical sceptical rationalism, there is an openended lack of conclusion. Accordingly, just as it does not validate an argument on a particular issue or adopt it as certain, nor does it reject the competing arguments or

54 II, 54 (112, 1. 25-114, 1. 9 = Bashir, 295-96). Halevi asserts here (112, 1l. 25-26 = Bashir, 295) that at the pre-Israelite stage of history, only a few unique chosen individuals - the same individuals to whom God revealed His signs (see III, 53 [204, 1l. 9-10 = Bashir, 408]) - were able to properly grasp God's attributes and His governance of the world. See the discussion in Krinis, God's Chosen People, 75-78.

55 II, 54 (114, 1l. 9-16 = Bashir, 296): “[This is how things were] until that group, which was worthy of the light coming to it, miracles being decreed for it, and the customary course of events being disrupted [for its sake], became pure, and it became obvious from experience (wa-zahara 'iyānan) that this world has a Ruler, a Preserver, and an ultimate Authority, who knows what is small and what is great and also requires good and evil. Thus, there came to be proper guidance for the hearts of men. No one who came after it was able \{to\} isolate himself from its fundamental principles, so that today the entire inhabited world acknowledges the eternity of God and the world's coming into being as a complete innovation. Their demonstration of that is the children of Israel themselves and both what He decreed on their behalf and what was decreed against them." 
take them off the table. The sceptical rationalist approach is reflected in the Khazar king's assessment in I, 24 that the general-universal attributes "were doubtful for me." The doubt that the Khazar king is talking about here is the outcome of him positioning the issue of God's attributes in the sceptical arrangement of the "equipollence of counter-arguments" in I, 20. The adoption of the sceptical stance which neither validates nor disproves the claim regarding God's attributes on the rational level of argument is portrayed as a temporary and intermediate station in the Khazar king's reorientation. Taking off from the dogmatic stance in I, 12, where the ability of the rational inquiry to establish God's universal attributes was taken for granted, in I, 24, he finally hits in on the conclusion that those attributes can only be firmly based on God's particular attributes (i.e., His attributes as "the God of Abraham, Isaac, and Israel," etc.). So, according to the message conveyed by the full-scale dynamic of the opening part of the dialogue between the rabbi and the Khazar king, the reorientation of a dogmatic rationalist and his transformation into a believer includes a midway stop at the sceptical station. Thus, while Halevi acknowledged scepticism as a rationalistic remedy for the disease of the dogmatic rationalist (or as a measure needed to awake him from his "dogmatic slumber"), he acknowledged it not from the point of view of the sceptic, but from that of the believer. ${ }^{56}$

Turning to I, 25, the rabbi presents a broader epistemological criterion for the Jewish credo: direct eyewitness perception (al-'iyān), already acknowledged by the Khazar king in I, 24, is here supplemented by “concurrent tradition” (al-tawātur):

The Rabbi said: Well, I answered you in the same way when you [first] questioned me; and Moses began addressing Pharaoh in the same way, too, when he told him, "The God of the Hebrews has sent me to you, ${ }^{57}$ meaning, the God of Abraham, Isaac, and Jacob, since their story was well-known among the nations as well as [the fact] that a divine order accompanied them, took interest in them, and performed wonders for them. He did not tell him, "The Lord of heaven and earth" or "My Creator and your Creator sent me." And God also began His address to the multitude of the children of Israel in the same way: "I am [the] God, whom you worship, who brought you out of the land of Egypt." ${ }^{58} \mathrm{He}$ did not say, "I am the Creator of the world and your Creator." Accordingly, I opened the conversation with you in this way, O commander of the Khazars, when you asked me about my faith (imāni). I answered you in terms of what is compelling for me and for the community of the children of Israel for whom that [which I have described] is well-established on the basis of eyewitness perception (al-iyān) and, subsequently, through concurrent tradition (al-tawātur), which is as valid as eyewitness perception (ka-l-'iyān). [I, 25]

56 That is why the end goals of scepticism, such as the Pyrrhonian "tranquillity" (ataraxia), are irrelevant for Halevi.

57 This quotation is a translation (in Arabic in original) of part of the verse in Exodus 7:16.

58 This quotation is a translation (in Arabic in original) of part of the verse in Exodus 20:2. 
This passage makes two references to the opening declaration of the rabbi's credo in I, 11 ("Well, I answered you in the same way when you [first] questioned me," "Accordingly, I opened the conversation with you in this way"). Yet the new formulation Halevi gives that credo here takes into account the development of the discussion from its starting point to its current position. It is therefore appropriate to view this section as a conclusion of the opening part of the dialogue between the rabbi and the Khazar king.

Below, I make no attempt to exhaust the discussion of this conclusion and its richness of meaning and aspects. Instead, I shall concentrate on one aspect that is central to the issue under discussion here: Halevi's clash with the dogmatic rationalism of his Andalusian Jewish compatriots and the epistemological aspect that constitutes the core of this clash.

Abraham ibn Ezra (d. 1164), a close colleague of Halevi, provided highly valuable evidence for this issue in a section of his exegesis of the first of the ten commandments (Exodus 20:2). The section begins with a question that Ibn Ezra quotes in Halevi's name: “Rabbi Judah Halevi, of blessed memory, once asked me: Why did [the Scripture] mention 'I am the Lord thy God, who brought thee out of the land of Egypt' rather than 'who made the heavens and the earth and you'?" In the rabbi's words in I, 25, Halevi himself gives a completely different answer from Ibn Ezra's reply to the exegetical question Halevi posed to him. Ibn Ezra reduces the theological importance of the direct sense experience perceived by the people of Israel to signs of God's governance of the people during the exodus from Egypt, evidence expressed in the Scripture as "who brought thee out of the land of Egypt.” According to Ibn Ezra, this articulation is secondary in importance to the beginning of the verse, "I am the Lord thy God." He explains this opening phrase in the spirit of the dogmatic rationalist approach as a reference to God's general-universal attributes that man can learn about or infer from an observation of His governance of the world and its order and design ("from the ways of God can the learned man know Him”). According to Ibn Ezra's exegesis, the intellectual cognition of these general attributes is beyond the grasp of the masses; it is available only to the learned among them. Because of this fact, it was necessary to add "who brought thee out of the land of Egypt," an addition adapted to the limited sensory perception of the masses. ${ }^{59}$

Compared to Ibn Ezra's interpretation, Halevi - via the words he has the rabbi speak in I, 25 (a conclusion of the dialogue in I, 11-25 as a whole) - turns the tables on understanding the importance and advantage of the second half of Exodus 20:2. According to him, the significance of the ending of the verse is that during the for-

59 Abraham ibn Ezra, Šemot, 131-32. See also the discussion in Warren Zev Harvey, "The First Commandment and the God of History: Halevi and Crescas vs. Ibn Ezra and Maimonides” [Hebrew], Tarbiz 57 (1988): 205-9. 
mative event in which God revealed Himself to the people of Israel at Mount Sinai, He was made known to the people through His particular attributes as the one who redeemed them from captivity and exile in Egypt. The formulation of the verse is thus meant to stress the primacy of these attributes (here, Halevi includes "the God of the Hebrews" and "the God of Abraham, Isaac, and Jacob") over the general-universal attributes (here, he includes "the Lord of heaven and earth," "my Creator and your Creator," and "I am the Creator of the world and your Creator") as part of the credo that is binding on "the community of the children of Israel."

Epistemologically, in Halevi's approach, the first commandment is formulated this way to show that cognition of God in Jewish belief is based on the eyewitness perception ('iyān) of those who left Egypt and stood at Mount Sinai. The alternate formulation of the commandment - "I am the Creator of the world and your Creator" - is disqualified because it is based not on this unique historical sense experience, but rather on general intellectual observation and inference. From the epistemological perspective, the concluding sentence of I, 25 is very important: "[This]is well-established on the basis of eyewitness perception (al-iyān) and, subsequently, through concurrent tradition (al-tawätur), which is as valid as eyewitness perception (ka-l-'iyān)." The rabbi repeats this idea using different language elsewhere in the book. ${ }^{60}$ In the concluding claim, Halevi points to the close connection between iyān and tawātur, which shows that Halevi is relying on the epistemological terminology of traditionalist Islam throughout the opening dialogue between the rabbi and the Khazar king in I, 11-25. In that traditionalism, 'iyān as direct eyewitness perception never stands on its own. It is connected to and understood through tawätur, a procedure ensuring the trustworthiness of the transmission of the witnessing to those who did not directly experience it with their own senses. ${ }^{61}$

While the rabbi has repeatedly referred to the term 'iyān in parts of the dialogue (I, 15; I, 24), this is the first time that the term tawätur is used. This term is so unique to the special doctrine of cognition in the Muslim tradition that it cannot be adequately translated from Arabic into other languages. The main sense of tawätur is the reporting of a large number of witnesses (habar mutāwatir) about an event at which they were present and which they experienced first-hand through their

$60 \mathrm{~V}, 14$ (330, 1l. 9-10 = Bashir, 540): "But we must accept what has been witnessed [by our ancestors in direct sense testimony] as well as the concurrent tradition [that reports it], which is as valid as what has been witnessed (wa-naḥnu yalzimuna qubūl al-mušāhadah wa-l-tawātur alad̄i huwa ka-lmušăhadah)." For the terms 'iyān and mušāhadah as synonyms, see II, 48 (108, 1l. 12-15 = Bashir, 290): "They [i.e., the people of Israel - E.K.] did not know how it happened that the glory of YHVH descended among them, how the fire of YHVH consumes their sacrifices, how they heard the Lord's address to them, and how everything that happened to them took place with respect to those things that [human] intellects can\{not\} concede to as possible were it not for eyewitness perception (al'iyān) and the direct sense testimony (wa-l-mušāhadah) [they saw], which cannot be rejected."

61 See Abrahamov, Islamic Theology: Traditionalism and Rationalism, 69 n. 14. 
senses (bi-l-'iyān, bi-l-mušāhadah). Subsequently, many of those witnesses, each on his own, report the event to others who did not witness it. Further still, the same report is transmitted from one generation to the next by a large number of reporters in many separate chains of transmission, each of which is independent of the others. ${ }^{62}$ The epistemological assumption underpinning the certainty of tawātur is that the many witnesses to the original event and the many separate chains of transmission by which the report of it is transmitted from one individual to another and from one generation to another preclude the possibility of distortion or falsification of that knowledge conveyed in that report. ${ }^{63}$ As I have noted, while the matter of the doctrine of rationalist awareness concerns the extraction of new knowledge from the knowledge of the senses, the doctrine of traditionalist Muslim awareness is opposed to any addition to what the witnesses to the event experienced with their senses. As a consequence, tawätur does not integrate any intellectual consideration requiring the use of the rules of logical inference. When the (evidentiary) choices of knowledge are validated by tawätur, the knowledge immediately and spontaneously becomes fixed in the recipient's consciousness, making it independent of the conditions of the rules of logic. ${ }^{64}$ The rabbi's claim at the end of his statement in I, 25, according to which the epistemological status of knowledge received through "concurrent tradition" (tawātur) is equal to the epistemological status of the "eyewitness perception" ('iyān) of the witness to the reported event (al-tawātur aladi huwa ka-l'iyān), is a claim that is congruent with the traditionalist Muslim approach, according to which the acceptance of knowledge with tawätur status about tradition from the prophet of Islam is equal to that of direct sense experience. Epistemologically, there is no difference. Through tawätur, the recipient of the tradition is in direct contact with the prophet, parallel to the direct connection of the witnesses who were near him and who transmitted their testimony of his words and deeds. ${ }^{65}$ This concluding assertion Halevi has the rabbi voice at the end of I, 25,

62 Arent Jan Wensinck and Wolfhart P. Heinrichs, “Mutawātir," in Encyclopaedia of Islam, Second Edition, vol. 7, ed. Clifford Edmund Bosworth, Emeri van Donzel, Wolfhart P. Heinrichs, and Charles Pellat (Leiden: Brill, 1993): 781-82; Gautier H.A. Juynboll, “Tawātur,” in Encyclopaedia of Islam, Second Edition, vol. 10, ed. Peri Bearman, Theirry Bianquis, Clifford Edmund Bosworth, Emeri van Donzel, and Wolfhart P. Heinrichs (Leiden: Brill, 2000): 381-82.

63 Binyamin Abrahamov, "Necessary Knowledge in Islamic Theology," British Journal of Middle Eastern Studies 20, no. 1 (1993): 22 n. 15; Zysow, The Economy of Certainty, 7-17. At several other points in The Kuzari, Halevi refers to this same epistemological assumption while using additional terms that were typical in the above-mentioned traditionalist Muslim discourse: conspiracy (iștilāḥ) and collusion in forgery (tawāțū'). See I, 48; III, 24, 31, 39 (188, ll. 27-28 = Bashir, 391), 41 (192, ll. 10-11 = Bashir, 395), 73 (220, 1.17 = Bashir, 428), IV, 3 (242, 1. 22 = Bashir, 441), 11 (252, 1. 13 = Bashir, 463). See also the discussion in Krinis, "The Arabic Background of the Kuzari," 49.

64 Al-Ġazālī, Halevi's famous older contemporary, explained tawātur in this manner. See Bernard Weiss, "Knowledge of the Past: The Theory of Tawātur According to Ghazālī," Studia Islamica 61 (1985): 92. See also Nasser, The Transmission of the Variant Readings of the Qur'ān, 65-76. 
which is repeated at the end of $\mathrm{V}, 14$, is a clear indication that an epistemology that is unique to the worldview of traditionalist Islam forms the foundation of the dialogue in I, 11-25. ${ }^{66}$

From a fideist point of view, the use of scepticism - in its classical version, that of non-assent - in the overall manoeuvre of I, 11-25 allows Halevi to maintain God's general-universal attributes. He thereby avoids falling into an extreme version of fideism, one that tends to invalidate any assumption upheld by the dogmatic rationalists. On the one hand, his sceptical non-assent enables Halevi to deny the certainty of God's general-universal attributes insofar as they rely on dogmatic rationalistic arguments such as the "argument from design" (I, 20). On the other hand, the same sceptical non-assent enables Halevi to restore those same attributes: because sceptical non-assent does not invalidate any argument (insofar as it does not validate it either), it does not prevent Halevi, the moderate fideist, from re-establishing those general-universal attributes on a given arational epistemological basis as secondary and subordinate to the particular attributes (I, 21-25).

To conclude the discussion in this sub-chapter, I would like to emphasise Halevi's originality in his conflation of traditionalist Islamic epistemology with fideist scepticism in I, 11-25. In their summae theologicae, the two most important rabbinic mutakallimūn, Dāwūd al-Muqammaș (fl. first half of the ninth century) and Sa'adia Gaon, stressed the issue of the reliability of tradition by incorporating some of the assumptions and terms that were prevalent in the traditional Islamic epistemological framework. Yet for both writers, tradition is defined as knowledge based upon revelation as recorded and transmitted in Scripture. The aim of al-Muqammaș's and Sa'adia's adaptations of this epistemological framework is to secure the reliability of God's revelation to the Hebrew prophets (first and foremost to Moses) against the Muslim anti-Jewish (and anti-Christian) accusations of the falsification (tahrīf) of God's revelation in the Jewish tradition of the Scripture (i.e., the Hebrew Bible). In this framework, which is closely related to the genre of the "signs of prophecy" (a 'àm/dal'âil al-nubuwwah) typical of the Arabic culture of this period, the complementary condition for "eyewitness perception" ('iyān) is not "concurrent tradition" (tawātur), but rather immunity from conspiracy to falsification (tawāțū') in the process of documenting the revelation in the Scripture. ${ }^{67}$ Thus, the centrality of orality in the transmission of revelatory events and contents forms a cornerstone of the Islamic traditionalist worldview and is accepted and adapted by Halevi in I, 11-25.

65 Zysow, The Economy of Certainty, 15.

66 For further discussion, see chapter 4 below.

67 Immunity from conspiracy to falsification or collusion in forgery (tawātū') serves as one of the conditions or characteristics of "concurrent tradition" (tawātur). See Pavel Pavlovitch, "Hadìth," in Encyclopaedia of Islam, THREE, ed. Kate Fleet, Gudrun Krämer, Denis Matringe, John Nawas, and Everett Rowson (consulted online on 06 February 2020. http://dx.doi.org/10.1163/1573-3912_ei3_COM_30163), sec. 7.1.1. 
However, it is of negligible importance in the adaptations of the traditional approach in al-Muqammaș's and Sa'adia's summae. ${ }^{68}$ Another notable Jewish mutakallim, Samuel Ben Hofni Gaon (d. 1013), did present an elaborate discussion of the concept of "concurrent tradition" (tawātur). He did so as part of his effort to develop a rabbinic science of "the principles of jurisprudence" (ușūl al-fiqh). In Samuel Ben Hofni Gaon's case, this development went hand in hand with his antiKaraite polemic. ${ }^{69}$ Yet these cases are in accordance with the rationalistic Mu'tazilite kalām's usage of the traditionalist framework: in al-Muqammaș's and Sa'adia's cases, the direction is that of the genre of the "signs of prophecy"; in Samuel Ben Hofni Gaon's case, it is that of the science of "the principles of jurisprudence" (ușūl al-fiqh). Halevi's case is altogether different. The insertion of components of fideist scepticism into I, 11-25 enabled Halevi to turn the traditionalist framework against the rationalistic Mu'tazilite assumption regarding the compatibility of knowledge acquired through human intellectual inquiry and the knowledge acquired through revelation and the transmission of tradition. ${ }^{70}$

\section{B The Kuzari I, 67}

I devoted the previous sub-chapter of this study to a discussion of the appearance of sceptical motifs in The Kuzari by analysing all of the dialogue in I, 11-25. By contrast, in the current sub-chapter, I shall focus on a single section: the rabbi's statement in I, 67, which constitutes a conclusion and summary of another section of dialogue between the rabbi and the Khazar king beginning with the rabbi's statements in I, 43. To this end, I must first say a few words about the contents and development of the dialogue in I, 43-67 and how it relates to the contents of I, 67, the focus of this sub-chapter of the study.

At the heart of the dialogue in I, 43-67 is the Arabic term ta'rīh, a word with different denotations: one refers to the date, a particular point in time, another to the enumeration of time from a certain starting point, and a third refers to the chronological or historical span of time. In the exchange that develops between the rabbi and the Khazar king in I, 43-44, Halevi uses the semantic field between two of the

\footnotetext{
68 Dāwud al-Muqammiș, Dāwud ibn Marwān al-Muqammiṣ’s Twenty Chapters ('Ishrūn Maqāla'), ed. and trans. Sarah Stroumsa (Leiden: Brill, 1989), 262-65; Sa'adia Gaon, al-Muhtār fì al-amānāt wa-l-i'tiqādāt, 130-31 (= The Book of Beliefs and Opinions, 156-57). See the discussion in Stroumsa, Freethinkers of Medieval Islam, 22-36 (especially 27, 33-34).

69 Sklare, Samuel Ben Hofni Gaon and His Cultural World, 158-63. We also find Halevi utilising traditionalist terms and patterns in his anti-Karaite polemic in the third part of The Kuzari. See Lobel, Between Mysticism and Philosophy, 56-58, 60-69; Krinis, "The Arabic Background of the Kuzari," 50-52.

70 For further discussion, see chapter 4 below.
} 
above-mentioned meanings of the word ta'rih . In the concluding sentence of I, 43, the rabbi speaks of the chronology [of the human race] from Adam onward (wa-lta'rīh min Ādam ilā halumma ğarā). Here, it seems correct to read ta'rīh as referring to history and its events, given the overall context of the rabbi's words in this section, which concern historical events and aspects of the development of humanity since the inception of time, as known to the people of Israel through the words of the prophet (i.e., Moses). The Khazar king's response in I, 44 - "It would be extraordinary if you had a reliable date (ta'rīh mutahaqqaq) for the creation of the world" shifts the readers to another meaning of ta'rih and the issue that is going to be the focus of the discussions between the Khazar king and the rabbi in the dialogue in I, 43-67: the issue of the specific enumeration of time from a certain starting point, which forms the reckoning of time in the Jewish tradition, and the reliability of this reckoning.

The epistemological foundation for the dialogue in I, 43-67 is generally the same as the foundation for the rabbi's statements in I, 11, which was the starting point of the dialogue in I, 11-25 discussed above. This is an epistemology that is typical of Muslim traditionalism, at whose core is the concept of reporting (habar, pl. $a h b \bar{a} r$ ) and the conditions for word-of-mouth transmission. This epistemological foundation links two meanings of ta'rih, that of the date of the beginning of the world (i.e., how long the world had existed) and that of historical events. The classical works of the early Muslim historiographical tradition began with the creation of the world and Adam as their starting point and continued with a description of historical events in chronological order up to the author's own time. ${ }^{71}$ In this Muslim historiographical tradition, a common genre was patterned in correlation with the accepted form of the oral tradition of Muslim literature; that is, a form consisting of reports $(a h b \bar{a} r)$ passed on from transmitter to transmitter as stand-alone units of separate, independent items, each of which was devoted to one particular historical episode. ${ }^{72}$

From the starting point of the connection between these two meanings of $t a$ 'rih and the traditionalist Muslim epistemology that characterises it, the debate in this section of the dialogue moves towards an issue that is also of great relevance from the dogmatic rationalist perspective. This is a clash of two contradictory claims about the origin of the world: the claim that the world has always existed and is

71 The rabbi's closing remark in I, 43 (22, 1. 4 = Bashir, 179), "as well as the chronology [of the human race] from Adam onward (wa-l-ta'rīh min Ādam ilā halumma ğarā)," resembles the framework of the Muslim historiographical tradition.

72 See Franz Rosenthal, A History of Muslim Historiography, 2nd rev. ed. (Leiden: Brill, 1968), 66-71; Fred McGraw Donner, Narratives of Islamic Origins: The Beginnings of Islamic Historical Writing (Princeton: Darwin Press, 1998), 255-60. 
eternal, a claim known as the claim of eternity a parte ante (qidam), ${ }^{73}$ versus the claim that God created the world ex nihilo at the point when time and its counting began. This claim was known as the claim of innovation (hadat). In I, 60, the dialogue shifts to the eternity-versus-innovation issue when the Khazar king asks the rabbi, as someone defending the Jewish chronology of the world, about "what is reported ( $m \bar{a}$ yuhbar) in the name of the people of India to the effect that they have historical relics and buildings that they determine to be a million years old?" When it is the Khazar king's turn to speak again in I, 62, he continues to press the rabbi on the issue, this time from the philosophers' point of view, saying "they have reached agreement on the eternity of the world a parte post (al-azaliyyah) as well as its eternity a parte ante (wa-l-qidam)." In his next statement in I, 64, the Khazar king assumes a more focused approach, identifying the eternity claim not only with philosophers in general, but also with Aristotle in particular, the philosopher par excellence in the rationalist tradition of Arabic culture. Responding to the Khazar king's comment on Aristotle in I, 65, the rabbi says that Aristotle "in his rational deliberations, decided in favour of the claim of eternity by means of his thinking alone" (rağaḥ qiyāsātahu al-qā'ilah bi-l-qidam bi-muğarrad fikrihi). Later in the same section, the rabbi complains that Aristotle focused his intellectual inquiry on proving the claim of eternity, thus inevitably neglecting to study the opposite claim of innovation. This criticism implies an underlying assumption identified with sceptical intellectual inquiry according to which it is possible and necessary to provide proofs of all the conflicting claims on the issue at hand. Just as it is possible to focus intellectual efforts to establish one claim, so is it possible to focus them on other contradictory claims. In his response in I, 66, the Khazar king wants to know if the rabbi can present a demonstrative proof (al-burhān) that would enable one to assent (tarğinh) to one of the opposite arguments concerning the origin of the world. This request for an assent offers the rabbi the opportunity to provide what Halevi considers to be the summarising and concluding answer to the debate:

The sage said: Who, indeed, could provide us with the demonstration (al-burhān) on this question (al-mas'alah)? God forbid that the Law should teach something that repudiates [the testimony of] eyewitness perception ('iyānan) or [the conclusion of] a demonstration (burhānan)! However, it does report miracles and the disruption of the customary workings [of things] (bimu'izāt wa-harq 'ādāt) by the creation of [entirely new] substances (bi-ihtirā' $a^{\prime} y \bar{a} n$ ) or by turning one substance into another (qalb 'ayn ilā 'ayn) to furnish proof for the [existence of the] Creator of the world (muhtari' al-'älam) and His power to do whatever He wishes, whenever He wishes. The question (mas'alat) of the [world's] eternity a parte ante (al-qidam) and of [its] innovation (al-hadat) is profound (g்amidah), and the proofs [in favour] of the two counter-arguments are equipollent/equivalent (wa-dalä'il al-ḥuğğatayin mutakāfi'ah). In that case, then, the tradition (al-naql) from Adam, Noah, and Moses, peace be upon them, based on prophecy,

73 A claim which can be distinguished from the claim that the world will continue to exist for ever (eternity a parte post). 
which is more trustworthy than reasoning (al-qiyās), tips the balance in favour of [its] innovation (yurağiḥu al-hadat). But even if (wa-ba'da an) ${ }^{74}$ an adherent of the Law (al-mutašarri') is forced to concede and acknowledge the existence of prime matter (hayūlā qadìma) and many worlds prior to this world, this should not count as a deficiency in his belief (laysa fi dalika mat' an fi i'tiqādihi) [as long as he holds] that this world came into new existence (ḥa dit $)$ at a specific time in the past (mundu muddah muhașșalah) and that its first human inhabitants (waawwal nāsuhu) were Adam and Noah (var. Adam and Eve). [I, 67] $]^{75}$

The rabbi's words are notable for their density and complexity. This is, in fact, one of the most problematic passages in The Kuzari. Scholars have found it difficult to parse and have proposed different, even contradictory explanations for it. I shall hereby present my own attempt to provide an understanding of it. It differs from previous explanations in that it sees the sceptical component as a key to understanding Halevi's intention in the words he has the rabbi speak.

The rabbi begins with a question: "Who, indeed, could provide us with the demonstration (al-burhān) on this question (al-mas'alah)?” The question (al-mas'a$l a h$ ) is unspecified here, being elucidated only later on: "The question (mas'alat) of the [world's] eternity in the past (al-qidam) and of [its] innovation (al-hadat)." The rabbi is answering the question the Khazar king posed in the previous section, which included the request for a demonstrative proof (al-burhān) allowing for an assent (tarǧĭh) and the settlement of the issue. The question that the rabbi posits in response to the Khazar king's query is rhetorical. In the discussion of the rabbi's words in I, 15 above, I noted the double meaning of the term burhān: it can mean a sign, in the sense of a concrete miraculous occurrence, but it can also mean an intellectual proof of the highest order of logic. The two meanings of burhān relate to two separate epistemological channels: in the sense of a miraculous occurrence, burhān relates to the recognition of an eyewitness perception ('iyān), whereas burhān in the sense of logical proof relates to abstract intellectual cognition. The formulation of the opening question in I, 67 as a rhetorical question hints at the answer: no one can provide demonstrative intellectual proof (burhān) that provides assent (tarǧih ) to one of the positions in the question of the origin of the world. In other words, the rabbi's opening statement in I, 67, phrased as a rhetorical question, hints at the sceptical answer to this particular question which he will explicitly

74 See Joshua Blau, Dictionary of Mediaeval Judaeo-Arabic Texts [Hebrew] (Jerusalem: The Academy of the Hebrew Language - The Israeli Academy of Sciences and Humanities, 2006), 45 (s.v. $b a^{\prime} d a$ ).

75 See, in this context, Daniel J. Lasker, "Adam and Eve or Adam and Noah? Judaeo-Arabic and Hebrew Versions of the Same Books," in Pesher Nahum: Texts and Studies in Jewish History and Literature from Antiquity through the Middle Ages Presented to Norman (Nahum) Golb, ed. Joel L. Kraemer and Michael G. Wechsler (Chicago: Oriental Institute of the University of Chicago, 2012), $141-48$. 
declare further on: it is impossible to provide demonstrative proof for either the eternity or the innovation of the world.

The major Judeo-Arabic writers distinguished between three sources of human cognition: the senses (hawāss), the intellect (al-'aql), and "a faithful tradition/report and truthful transmission" (al-ḩabar al-șādiq wa-l-naql al-ṣaḥih). This division can be traced back to Sa'adia Gaon's The Book of Beliefs and Opinions ([al-Muhtār fi] alamānāt wa-l-i'tiqādāt), a model of dogmatic rationalism. But Sa'adia spoke of four sources, the third of which he called "necessary knowledge" ('ilm al-darūriyyāt). ${ }^{76}$ The more relevant formulation relating to the three-part division above appears in Bahya ibn Paqudah's The Book of Direction to the Duties of the Heart (Kitāb alhidāyah ilā farā'iḍ al-qulūb $)^{77}$ and forms the framework for the rabbi's inquiry into the origin of the world in I, 67. The inquiry begins by examining the two epistemologies related to the word burhān - the experience of the senses and the cognition of the mind - and only then arrives at the third source of knowledge, that of tradition.

Unlike the answer embedded in the rhetorical question Halevi formulates at the outset of the rabbi's words in I, 67, the declaration he makes immediately thereafter - "God forbid that the Law should teach something that repudiates [the testimony of] eyewitness perception ('iyānan) or [the conclusion of] a demonstration (burhānan)" - leaves an immediate impression of a dogmatic rationalist line. According to this widespread approach, the opinions expressed in the Torah, including the innovation of the world, are corroborated by sources of human cognition. ${ }^{78}$ However, as mentioned earlier in our discussion of The Kuzari I, 11-25, while rationalists of Sa'adia Gaon's type recognise the legitimacy of only one type of rationalism - the dogmatic kind - Halevi recognises the legitimacy of an additional form of rationalism: the sceptical kind. ${ }^{79}$ As I demonstrate below, the rabbi's remonstration - "God forbid" - must be read not in a dogmatic rationalist context, but in a sceptical rationalist one.

76 Sa'adia Gaon, al-Muhtār fì al-amānāt wa-l-i'tiqādāt, 14-15 (= The Book of Beliefs and Opinions, 16-18).

77 Baḥya ibn Paqudah, Kitāb al-hidāyah ilā farā'iḍ al-qulūb, 82-83 (=The Book of Direction to the Duties of the Heart, 141).

78 See, for example, Sa'adia Gaon, al-Muhtār fì al-amānāt wa-l-i'tiqādāt, 24-25 (= The Book of Beliefs and Opinions, 27-28).

79 Sa'adia Gaon did have what seems to be a vague idea regarding one of classical scepticism's main tenets. We can adduce this from his fierce criticism of "the school [of those who espouse] suspension" (madhab al-wuqūf). The term wuqūf and his derivations stand here, as well as in some other instances in Arabic and Judeo-Arabic literature, for the basic sceptical notion of the "suspension of judgment” (epochē). See Sa'adia Gaon, al-Muhtār fi al-amānāt wa-l-i'tiqādāt, 6971 (= The Book of Beliefs and Opinions, 80-82). See also Heck, Skepticism in Classical Islam, 30, 38; Crone, Islam, the Ancient Near East and Varieties of Godlessness, 125; Stern, The Matter and Form of Maimonides' Guide, 85 n. 18. 
The rabbi first addresses the part of his assertion, which says that the Torah's claim about the innovation of the world is not denied by human eyewitness perception ('iyānan). Continuing on this point, the rabbi speaks of the "miracles ( $m u$ ' and the disruption of the customary workings [of things] (mu'ğizāt wa-harq 'ādāt) by the creation of [entirely new] substances (bi-ihtirāa' $\left.a^{\prime} y \bar{a} n\right)$ or by turning one substance into another (qalb 'ayn ilā 'ayn) to furnish proof for the [existence of the] Creator of the world (muhtari' al-'älam)." In Halevi's thought, the Arabic terminology based on the verb ihtara', which appears twice in this section (bi-ihtirā' a $\bar{c}^{\prime} y \bar{a} n, m u h$ tari' al-'ālam), is closely related to creation ex nihilo and the concept of innovation (al-hadat). ${ }^{80}$ In Sa'adia Gaon's introduction to his discussion of the origin of the world, God's miracles - signs and [miraculous] demonstrations (bi-l-āyāt wa-lbarāhin), as he calls them - are considered to be decisive proof of the Torah's claim that the world was created (as well as of all the other claims in the Torah). ${ }^{81}$ The situation for Halevi is different because of the special importance he attributes, both here and elsewhere, to the criterion of eyewitness perception ('iyān) as something belonging to a separate arational epistemological order. ${ }^{82}$ From this perspective, there is an essential difference between the innovation of the world and miracles: while miracles can be accessed by the channel receiving direct sense experience, the innovation of the world cannot. ${ }^{83}$ This is why the rabbi, in I, 67, cannot satisfy the request he has the Khazar king make in I, 66 on the basis of miracles. Thus, for Halevi, miracles are corroboration for the Torah's claim of the innovation of the world, but not decisive proof of it.

Halevi now proceeds to the second source of knowledge of human cognition the intellect - in which assent to one position is attained on the basis of demonstrative proof (al-burhān). When the rabbi speaks of this source, the congruence with the sceptical method surfaces. The rabbi's statement - "The question (mas'alat) of the [world's] eternity a parte ante (al-qidam) and of [its] innovation (al-hadat) is profound (g்amidah), and the proofs [in favour] of the two counter-arguments are

80 See I, 8 (12, 1l. 25-28 = Bashir, 167-68); 91 (42, 1l. 13-17 = Bashir, 205); V, 14 (324, 11. 25-28 = Bashir, 535).

81 Sa'adia Gaon, The Book of Beliefs and Opinions, 40 (=al-Muhtār fi al-amānāt wa-l-i'tiqādāt, 35): "Furthermore thou hast over (tarağğuḥ) them the advantage of being in possession of signs and [miraculous] demonstrations (bi-l-ayāt wa-l-barāhinn) that have been established for thee [as trustworthy]."

82 See the discussion in the previous sub-chapter.

83 Sa'adia Gaon had already dealt with the impossibility of there having been an eyewitness account of the innovation of the world ('iyān) in The Book of Beliefs and Opinions, 38 (= al-Muhtār fi alamānāt wa-l-i'tiqādāt, 33):“The author of the book said: 'This treatise [titled: Concerning the Belief That all Things Were Created - E.K.] starts out with the preliminary observation that whoever ventures into it is seeking [light on] something that has never been beheld with human eyes nor been perceived by the senses (lam yaqa'u 'alaihi al-'iyān wa-lā adraktuhu al-ḥawāss), but can nevertheless ascertain by means of rational inferences (yarūmu ị̂tbātahu min țarīq al-istidlāl).” 
equipollent/equivalent (wa-dalā’il al-ḥuğğatayin mutakāf'iah)” - is the most conspicuous evidence in all of The Kuzari of Halevi's familiarity with sceptical terminology. The beginning of the statement - "The question of the [world's] eternity a parte ante (al-qidam) and of [its] innovation is profound (g்amidah)" - is an entrée to classical scepticism, a way of thought that stresses the difficulties facing anyone attempting to deal with theoretical questions. ${ }^{84}$ Accordingly, sceptical thinkers often point to the quality of rashness - propeteia - as being typical of the method of argument used by their dogmatic rivals. ${ }^{85}$ The dogmatic thinkers' tendencies to prefer one claim over others and to take a side on any given issue is considered frivolous by the sceptical thinkers, given the difficulties that these questions pose. The end of the rabbi's speech - "the proofs [in favour] of the two counter-arguments are equipollent/equivalent” (wa-dalā'il al-ḥuğğatayin mutakāfi'ah) - brings us directly to the heart of classical scepticism. Here, Halevi also inserts a variation on a fundamental concept of sceptical thought, the most prominent concept (and one of only a few) to have received a clear and consistent translation in Arabic literature of the classical Islamic period: isostheneia (the equipollence/equivalence of counter-arguments), rendered in Arabic literature as takäfu' al-adillah. ${ }^{86}$

As for the historical background of the rabbi's statement, it is especially important to point to its similarity, both in content and in formulation, to the claim which, in Arabic culture, was recognised as having been made by Galen, the famous Hellenistic physician and writer. In his writing, Galen argued a great deal with sceptics and medical schools that applied the sceptical approach to the practice of medicine. ${ }^{87}$ At the same time, in several places, Galen himself adopted a sceptical approach to the question of the world's innovation or eternity. ${ }^{88}$ The importance of these facts is linked to the possibility that Galen, many of whose voluminous medi-

84 In other places in the book, derivations of the Arabic verb g.m.d appear in the context of issues that are either inaccessible or very difficult to understand. See I, 91 (42, 1. 13 = Bashir, 205); IV, 25 (274, 1. 12 = Bashir, 490); 31 (292, 1. 22 = Bashir, 510); V, 21 (353, 1. 18 = Bashir, 562).

85 See Sextus Empiricus, Outlines of Scepticism, index, s.v. "rashness, Dogmatic” (246); Cicero, On Academic Scepticism, glossary, s.v. "rashness” (141). See also Richard H. Popkin and José R. Maia Neto, eds., Skepticism: An Anthology (Amherst, NY: Prometheus Books, 2007), 23.

86 Perlmann, "Ibn Hazm on the Equivalence of Proofs"; Van Ess, "Skepticism in Islamic Religious Thought," 90; Kraemer, “About the Arabic Sceptical Philosophy," 212; Kraemer, Humanism in the Renaissance of Islam, 15, 180-81, 189-91; Heck, Skepticism in Classical Islam, 14-15, 75-81, 197-98; Crone, Islam, the Ancient Near East and Varieties of Godlessness, 126. While "equipollence of counter-arguments" is the translation used for the Greek term isostheneia by scholars of Hellenistic thought, scholars of Arabic thought translate the Arabic term takäfu' al-adillah as "equivalence of counter-arguments."

87 See De Lacy, “Galen's Response to Skepticism.”

88 De Lacy, 304; Barnes, The Toils of Scepticism, 4-5. 
cal and philosophical tracts were translated into Arabic, ${ }^{89}$ served as a channel whereby those familiar with Arabic culture were exposed to the opinions of the Hellenistic sceptics. In his commentary on Aristotle’s Topics, al-Fārābī (d. 950) noted the connection between Aristotle's discussion of the difficulty posed by a question such as the world's innovation or eternity (Topics 104b) and Galen's comments on the same. ${ }^{90}$ In this context, al-Fārābi polemically argued that Galen's own failure to reach a demonstrative proof in this question was the reason why he had argued for the equipollence/equivalence of the counter-arguments in this case. ${ }^{91}$ Unlike alFārābī, al-Ġazālī, in The Incoherence of the Philosophers (Tahāfut al-falāsifah), notes the possibility that Galen arrived at the state of non-assent regarding the innovation/eternity question not because of his lack of intellectual capacity, but because the question itself lies outside the scope of the intellect's grasp. ${ }^{92} \mathrm{Halevi}$, who was a physician by trade, was familiar with Galen's scientific works, which had been translated into Arabic, and he mentions him and a few of his works and opinions in The Kuzari. ${ }^{93}$ All of the above would indicate that it is very possible that Halevi was either directly or indirectly relying on Galen in his sceptical assessment of the equipollence/equivalence of counter-arguments in the question of the world's eternity or innovation, which he places in the rabbi's mouth in I, 67.

From the apologetic perspective, whose starting point would be the rabbi's earlier declaration "God forbid that the Law should teach something that repudiates [the testimony of] eyewitness perception ('iyānan) or [the conclusion of] a demonstration (burhānan)," we see that the defence Halevi chose to give the Torah which, according to him, maintains the world's innovation - does not rely on the dogmatic rationalist approach. A detailed example of the way in which a dogmatic rationalist would tackle this issue may be found in the first chapter of Sa'adia Gaon's dogmatic work The Book of Beliefs and Opinions, where the author defends

89 See Véronique Boudon-Millo, “Galen,” in Encyclopaedia of Islam, THREE, ed. Kate Fleet, Gudrun Krämer, Denis Matringe, John Nawas, and Everett Rowson (consulted online on 06 February 2020. http://dx.doi.org/10.1163/1573-3912_ei3_COM_27365).

90 Georges Vajda, “A propos d'une citation non identifiée d'al-Fārābī dans le 'Guide des Egarés,” Journal Asiatique 253 (1965): 43-50. Vajda, who located and identified al-Fārābī’s commentary, also recognised it as the source for Maimonides's citation in The Guide of the Perplexed II, 15.

91 "Therefore, because Galen the physician failed in achieving a demonstrative proof for this certain issue, he assumed there is no demonstrative proof for it, and that [the different] proofs related to it are equipollent" (zanna innahu lā burhān 'alayhi wa-inna al-barāhīn fihi mutakäfi'ah). See Vajda, “A propos d'une citation non identifiee d'al-Fārābī dans le 'Guide des Egarés,” 48.

92 Abū Ḥāmid al-Ghazālī, The Incoherence of the Philosophers, trans. Michael E. Marmura (Utah: Brigham Young University Press, 1998), 12 (Arabic and English). See also Frank Griffel, "Taqlid of the Philosophers: Al-Ghazālī's Initial Accusation in the Tahäfut," in Ideas, Images, and Methods of Portrayal: Insights into Classical Arabic Literature and Islam, ed. Sebastian Günther (Leiden: Brill, 2005), 291.

93 IV, 31 (288, l. 6 = Bashir, 404); V, 8 (= Bashir, 517); 21 (354, 1l. 4-6 = Bashir, 562). 
the opinion that the world was innovated as a claim asserted by the Torah using the apodictic mode of argumentation; namely, using proofs that he considered to be decisive for the innovation argument. Later in the chapter, Sa'adia Gaon refutes all variations of the opposite claim of the world's eternity. Unlike that approach, Halevi's concise argumentation defending the rationalism of the ex nihilo claim in I, 67 is aligned with the classical sceptical approach, according to which, as a result of being equipollent, the innovation argument has, rationally speaking, an identical status to the eternity argument. The possibility that the innovation argument is true holds, though not because its veracity has been demonstratively proven, but rather because it remains undetermined by the competing eternity argument and has therefore also not been refuted.

In defending the rational status of the innovation of the world in the spirit of sceptical rationalism by declaring the rationality of non-assent to any conflicted position instead of defending it apodictically as dogmatic rationalists would, Halevi placed himself in an essentially different position from the dominant stance in Judeo-Arabic thought. In the aftermath of Sa'adia Gaon, the apodictic mode of argumentation was also adopted by Andalusian Jewish writers who were contemporaries of Halevi, including Bahya ibn Paqudah and Joseph ibn Șaddiq (d. 1149). ${ }^{94}$ This position provided unequivocal backing for the human intellect's ability to provide decisive proofs in favour of the claim that the world was created ex nihilo, which simultaneously also served to refute the claim of the world's eternity. The statement Halevi has the rabbi voice regarding the equipollence of proofs on the eternity-versus-innovation question is meant, with one terse, carefully considered expression, to land a stunning blow on the optimistic climate of Judeo-Arabic dogmatic rationalism that preceded the author's era. This dogmatic rationalism generally sought to find the cornerstone for its theological method precisely in such intellectual proofs for the innovation of the world. Thus, by undermining this cornerstone, Halevi was in fact undermining the entire theological structure built upon it. In doing so, he anticipated Maimonides, who, two generations later, would turn the claim of a lack of decisive proofs in the eternity-versus-innovation question (a claim which he explicitly linked to Galen via al-Fārābi $)^{95}$ into the focus of his discussion of the issue in his Guide of the Perplexed. ${ }^{96}$

\footnotetext{
94 Bahyya ibn Paqudah, Kitāb al-hidāyah ilā farā'iḍ al-qulūb, 52-58 (= The Book of Direction to the Duties of the Heart, 116-21); Joseph ibn Șaddiq, The Microcosm of Joseph Ibn Șaddiq, ed. Saul Horovitz, trans. Jacob Haberman (Madison, NJ: Fairleigh Dickinson University Press, 2003), 4849 (Hebrew text), 111-12 (English text).

95 Maimonides, Dalālat al-hǟirīn II, 15 (203, 1. 27-204, 1. 2) (= The Guide of the Perplexed, 292).

96 Maimonides, Dalālat al-ḥā'irīn I, 71 (124, ll. 19-21); II, 16 (204, 1l. 12-19); II, 22 (223, 1. 22-224, 1. 7); II, 25 (230, 11. 20-24) (= The Guide of the Perplexed, 180, 293, 320, 330). See Sara Klein-Braslavy, "Maimonides's Interpretation of the Verb 'Bara' and the Creation of the World” [Hebrew], Da'at 16 (1986): 43-48, 53-55. See also the discussion in the next chapter.
} 
From the second source of human knowledge, the intellect, Halevi transitions to the third - tradition (al-naql):

In that case, then, the tradition (al-naql) from Adam, Noah, and Moses, peace be upon them, based on prophecy, which is more trustworthy than reasoning (al-qiyās), tips the balance in favour of [its] innovation (yurağğị̣u al-ḥadat).

This assertion - that the issue under discussion is to be settled by tradition based on prophecy - bears an explicit fideist message. With this fideist judgment, stressing the superiority of tradition over reasoning, Halevi sets his approach apart from the common approach in the Judeo-Arabic dogmatic rationalism of his time. The latter championed a harmonistic approach whereby tradition backs and supports the findings of reasoning and intellectual inquiry, and vice versa. The rabbi's words in I, 67 make it clear that of the three sources of knowledge he mentions in this paragraph - namely, proofs from miracles, proofs from reasoning, and proofs from tradition - in this case, he considers the decisive source of cognition in the theological question at stake to be tradition (al-naql): the transmission of reports about the event by those who experienced it first-hand through their senses in a chain of oral history. In the case at hand, the transmission started with Adam and continued through other transmitters, including Noah and Moses.

The message we may elicit from the rabbi's statement regarding the decisive role reserved for tradition in determining the question of the world's innovation versus its eternity makes it suitable to serve as the rabbi's final concluding statement in this affair. It seems that the answer to the Khazar king's request for assent (tarğịh) in I, 66 has finally been satisfied. But instead of ending here, the rabbi continues and adds the following clarification to this seemingly decisive message:

\footnotetext{
But even if an adherent of the Law (al-mutašarri) is forced to concede and acknowledge the existence of prime matter (hayūla qadìma) and many worlds prior to this world, this should not count as a deficiency in his belief (laysa fi dalika maț an fi itiqādihi) [as long as he holds] that this world came into new existence at a specific time in the past and that its first human inhabitants (wa-awwal nāsuhu) were Adam and Noah (var. Adam and Eve).
}

The rabbi's clarification seems to remove much of the sting from his earlier words on the decisive role reserved for tradition. The difficulty in understanding what he is getting at here and in bringing these words into line with his previous statement lies in the meaning of the term "came into new existence" (hâadit $)$. According to Sa'adia Gaon's approach, which greatly influenced Judeo-Arabic thought, "new existence" in the sense of God's innovation of the contents of the world necessarily implied creation ex nihilo. To quote Sa'adia: "Our Lord, exalted be He, made it known to us that all things were created (muhditah), and that He had created them out of nothing (ahdatahā lā min šay'). Thus Scripture says: In the beginning God cre- 
ated the heaven and the earth (Gen. 1:1)."97 According to this standard understanding, it is impossible to agree with what the rabbi says here; that is, that it does not constitute a flaw in a fundamental tenet of belief ( $i$ tiqād) of "an adherent of the Law" (al-mutašarri') if he only partially adheres to the meaning of the term "came into new existence" (hâdit), in a way that incorporates an assumption of eternity into the concept of innovation, even though this eternity is not consisted with the best-known philosophical sense to which the Khazar king referred earlier in I, 62. From the perspective of a rationalist theological understanding à la Sa'adia Gaon, any stance that does not include an unequivocal recognition of creation ex nihilo represents a major flaw in the beliefs of that "adherent of the Law."

However, even in this case, as in others, Halevi shows himself to be conceptually independent, paving his own way when it comes to the phrase "innovation," a way that significantly differs from the understanding of Sa'adia Gaon and the Jewish dogmatic rationalists who followed in his wake. The creation of the world, in the sense Halevi gives it, means "that this world came into new existence (hāadit ) at a specific time in the past and that its first human inhabitants (wa-awwal nāsuhu) were Adam and Noah (var. Adam and Eve).” This original definition Halevi provides via the rabbi is notable for the fact that its chronological aspect overshadows its ontological-cosmological one. In the standard definition of "came into new existence," that of the world having been created ex nihilo, the ontological-cosmological aspect is essential, whereas in the rabbi's definition - one that tolerates the possibility of the existence of a prior substance and/or previous worlds - the ontological-cosmological aspect loses its essential core status. In this definition, the centre of gravity is shifted to the stance whereby the world "came into existence at a specific time in the past (hādit mundu muddah muhașșalah)" - that is, in accordance with the reckoning of years in the traditional Jewish sources - and "that its first human inhabitants (wa-awwal nāsuhu) were Adam and Noah"; that is, the figures the rabbi mentioned earlier in the section as having played a key role in the transmission of the tradition (al-naql) reaching to Moses. From a broader perspective, we see that the rabbi's definition at the end of I, 67 is an apt conclusion and summary of the dialogue between the rabbi and the Kuzari in I, 43-67, because with this definition of "came into new existence," the rabbi returns the discussion to his central issue of this section: that of the chronology and reckoning of years (ta'rih) in the Jewish tradition and its reliability.

The novel definition of "came into new existence" with which Halevi concludes the rabbi's words in I, 67 sheds light on the meaning of the rabbi's previous declaration about the decisive role reserved for tradition (al-naql) in the context of the innovation/eternity debate. The kind of decisive role that the rabbi mentioned is valid

97 See Sa'adia Gaon, al-Muhtār fì al-amānāt wa-l-i'tiqādāt, 35 (= The Book of Beliefs and Opinions, 40). 
only for the chronological definition presented in his subsequent statement and is an assent equivalent to a decision in favour of the veracity of the reckoning of years in the Jewish tradition. ${ }^{98}$ At the same time, this assent does not apply to the ontological-cosmological definition of "came into new existence" ex nihilo. Consequently, an assent that is dependent on tradition rules out only one particular understanding of eternality, one whose chronological aspect contradicts the chronological characterisation of the reckoning of years in the Jewish tradition. Through the words he places in the rabbi's mouth at the end of I, 67, Halevi is willing to accommodate some versions of the eternity argument, such as the one assuming the existence of a prime matter, whose assumptions do not necessarily lead to a clash with the fundamental assumptions of Jewish chronology. However, he cannot show a similar flexibility towards the version of eternity espoused by falsafah, which denies innovation before "a specific time in the past" and also the existence of "first human inhabitants" (i.e., the biblical Adam and Noah [var. Adam and Eve]). This is the version of eternity that Halevi put into the mouth of the philosophers' spokesperson who presented his view to the king in I, 1: "In fact, He did not create man at all because the world is eternal; and man has never ceased coming into being out of a man before him." 99

Various statements in The Kuzari would seem to indicate that Halevi himself tended towards the ex nihilo view, seeing it as a most proper and desirable opinion. ${ }^{100}$ Thus, his willingness to compromise with some other positions at the end of I, 67 implies that even though the ex nihilo understanding of the world's innovation is correct and desirable, it is not, in Halevi's approach, a core tenet of Jewish belief. This is backed by the rabbi's last words in I, 67 and the connection Halevi makes between the "adherent of the Law" (al-mutašarri') and what should be regarded as

98 From the context in I, 67, it seems that it is the component of prophecy mentioned here ("the tradition from Adam, Noah, and Moses, peace be upon them, based on prophecy") that safeguards the veracity of the tradition of the chronology of the world. However, elsewhere in The Kuzari, both in I, 47 and I, 95, Halevi makes it clear that the veracity of this chronology derives from the special status of its transmitters, the "unique individuals" (afräd).

99 I, 1 (4, 1l. 5-6 = Bashir, 154). See also V, 14 (324, 1. 20-21 = Bashir, 535). Compare with the rabbi's words at the end of I, 61, where the universal chronology reflected in the Book of the Nabatean Agriculture (Kitāb al-falāhah al-nabatịyah) is rejected on the grounds that it specifies the names of people who were Adam's predecessors.

100 See IV, $3(228,1.24$ = Bashir, 436): "This confirms for him that He is the one who created the world after its [prior] non-existence"; V, 14 (324, 11. 24-28 = Bashir, 535): "As for the opinion of the Law, it is that God created the world as it is, with its animals and plants fully formed so that there is no need for the pre-existence of simple elements and the formation of compounds. By affirming the complete innovation of the world every difficulty becomes easy [to resolve]. Moreover, every impossibility can be removed, if you were to imagine that this world did not exist and then came to be through God's wish, at the time He wished and in the manner He wished." See also I, 91 (42, 1l. 1318 = Bashir, 205); V, 18 (332, 11. 7-27 = Bashir, 542-43). 
a core tenet (i'tiqādihi) of one such "adherent of the Law." The "adherent of the Law" - in this case, an adherent of the Mosaic Law ${ }^{101}$ - is bound by the credo of his religion. The fact Halevi states here that it is possible for an "adherent of the Law" to accept the existence of a prime matter or that other worlds preceded this one and that "this should not count as a deficiency in his belief" (laysa fi dalika maț an $f i$ i'tiqādihi) teaches us that from his perspective, the belief in the world's innovation ex nihilo is not a core tenet of the Jewish credo, one that is incumbent upon a Jewish "adherent of the Law" without any exceptions. By contrast, a binding belief that does reach the level of a core tenet is the belief in the chronological facts "that this world came into new existence at a specific time in the past and that its first human inhabitants (wa-awwal nāsuhu) were Adam and Noah."

The conclusion that Halevi draws at the end of I, 67 that belief in the world's innovation ex nihilo is excluded from the Jewish credo is completely in keeping with the course of the dialogue in I, 11-25 analysed above. Innovation ex nihilo - that is, the innovation of the world in the ontological-cosmological sense - cannot be directly apprehended by the human senses and therefore fails the criterion of eyewitness perception ('iyān) which the rabbi introduced in I, 11-25 as the fundamental epistemological criterion upon which the core tenets of the Jewish credo rest. By contrast, belief in innovation in the chronological sense - that is, "the belief that this world came into new existence at a specific time in the past and that its first human inhabitants were Adam and Noah" - does meet the fundamental epistemological criterion of eyewitness perception ('iyān). This direct sense experience is then transmitted in a chain of transmitters from those who directly experienced the innovation of the world (i.e., Adam and Noah), being, in a sense, each in his own era, its "first human inhabitants (awwal nāsuhu)." ${ }^{102}$ Thus, this core tenet dovetails

101 This can be adduced from the fact that the tradition ( $a l$-naql) to which the rabbi is referring here is a tradition that goes as far as Moses ("the tradition from Adam, Noah, and Moses").

102 Consider the earlier exchange between the rabbi and the Khazar king in the same section of dialogue (I, 43-67): "The sage said: Have you heard of a nation that diverges from the well-known week, which begins with Sunday and ends with the Sabbath? Is it possible, then, that the inhabitants of China could agree with the inhabitants of the western islands on that [seven-day week] without a [common] beginning as well as meeting together and [reaching] an agreement? The Khazar said: That [kind of common institution] is possible only with the agreement of everyone. But this is unlikely, unless all people are descendants of Adam, or descendants of Noah, or of someone else. Then, the [seven-day] week would be transmitted, according to them, from their [common] ancestor. The sage said: This is what I meant. Furthermore, men in the East and the West agree on [the mathematical importance of] the number ten. What peculiar feature prompts their stopping at ten, if not the fact that it was taken from a [common] beginning?" (I, 57-59). Halevi's arguments in I, 57-59 about the universal usage of the seven-day week and the decimal system are in line with his argument in I, 67. All of them are directed to establish the innovation of the world in the sense of Adam and Noah's position as the "first human inhabitants." 
with the second and complementary criterion that Halevi posited in I, 25, that of trustworthy tradition. ${ }^{103}$

In Halevi's approach, the description of God in I, 25 as "the Creator of the world" (hāliq al-'âlam) is certainly correct and true, yet he did not make it in the rabbi's credo in I, 11. In I, 25, he also explained why this description was not included when God introduced Himself in the first of the ten commandments. Those articulations explain why the belief in creation ex nihilo, despite the fact that it is true and correct, is not obligatory for an "adherent of the Law" as a core tenet of belief (i tiqād). Halevi uses the same arguments and the same theological innovation in both I, 11-25 and I, 67. In both discussions, this daring innovation relies on Halevi's acceptance of a sceptical distinction which dogmatic rationalists, bound by the search for determination, are incapable of accepting. In both discussions, Halevi uses the unique sceptical rationale of non-assent as a tactical tool for uprooting the pretensions of dogmatism from certain key principles that the dogmatic rationalists viewed as Judaism's most intrinsic doctrines. As part of the discussion in I, 67, Halevi's tactical use of sceptical rationalism helps him to place creation ex nihilo in a sort of midway position: this opinion has not been refuted by the counter-argument of the world's eternity, allowing the Jewish believer to point to its rationalism, even though it does not meet the sensual epistemological criteria that would make it into a core tenet of belief, making it absolutely binding on a Jewish "adherent of the Law." 104

103 The absence of a tenet concerning the reliability of the Jewish chronology and reckoning of years ( $\left(a^{\prime} r \bar{h}\right.$ ) from the rabbi's credo in I, 11 can be explained (from an epistemological point of view) by the fact that it is backed by the transmission of only one chain of transmitters and not by the concurrent transmission (tawātur) of many chains of transmitters required by the rabbi in I, 25. However (as already noted), the rabbi's assertions in I, 47, and I, 95 (22, 11. 10-18; 44, 11. 11-19= Bashir, 181-81; 208-9) gives the impression that the reliability of the Jewish chronology and reckoning of years is guaranteed by the fact that each of its transmitters belongs to the chosen unique individuals ( $a$ frā $d$ ) of the early historical eras.

104 The failure of previous scholars to fully address the nuances in Judah Halevi's treatment of the question at hand in I, 67, nuances that included the ad hoc implementation of the sceptical version of rationalism, has yielded misinterpretations such as the two conflicting interpretations by David Kaufmann and David Neumark. These interpretations are both built on the incorrect assumption that Halevi is dogmatically committed to one of the two positions under discussion in I, 67: either he is committed to the position of the innovation of the world ex nihilo (as Kaufmann interprets it) or he is committed to the position of the existence of prime matter (as Neumark interprets it). The possibility that Halevi avoids the trap of being dogmatically committed to one of those conflicting positions by incorporating a sceptical stance was left unnoted by those two scholars (as well as by many others). See David Kaufmann, Studies in the Hebrew Literature of the Middle Ages, trans. Israel Eldad (Jerusalem: Mossad ha-Rav Kook, 1962), 208-11 [Hebrew]; David Neumark, Judah Hallevi's Philosophy in Its Principles (Cincinnati: Hebrew Union College Press, 1908), 24-25. 
Finally, when we turn to the Khazar king's immediate reaction to the rabbi's discussion of the question of the world's innovation versus its eternity, we find it to be very illuminated:

The Khazar said: These persuasive arguments (al-ḥuğağ al-muqni'ah) are enough for me on the subject [for now]. If my companionship with you should last, I will assign you the task of presenting me with arguments that are conclusive (al-ḥuğağ al-qāṭi'ah). [I, 68]

Above, we saw that in the dialogue between the Khazar king and the rabbi in I, 1125 , the insertion of the sceptical exposition of the issue under discussion there the argument from design) serves as a turning point in the discussion between the two interlocutors. This is particularly striking because in this part of the dialogue, the sceptical exposition was spelt out by the Khazar king (I, 20) and met with tacit approval from the rabbi (I, 21). On the other hand, in the course of the discussion between these two interlocutors, when they turn to the question of the world's innovation or eternity, the sceptical argumentation is articulated by the rabbi. In this case, the Khazar king finds himself unable to internalise it. His expectation that he will later receive "arguments that are conclusive" (al-ḥuğağ al-qāți'ah) from the rabbi in I, 68 stands as a stark misunderstanding or rejection of the rabbi's straightforward sceptical clarification that no such conclusive arguments can be adduced on behalf of either side of the innovation/eternity conundrum. Therefore, when it comes to the Khazar king (as an imaginative representative of Halevi's real interlocutors in his circle of friends and associates), we can locate two very different scenarios regarding his ability to absorb and accept the sceptical mode of argumentation. The first is the optimistic scenario in I, 11-25, where the king takes an active role in the process of deliberation aiming to shake up dogmatic rationalistic assumptions with the aid of sceptical rationalistic ones. The second is the pessimistic (albeit more realistic) scenario in which this kind of process fails as a result of the Khazar king's inability to acknowledge the emancipatory power of sceptical argumentation to awake him from his “dogmatic slumber.” The Khazar king's response in the opening of I, 68 exposes him as someone who is still very much immersed in the state of "dogmatic slumber," unable to awake in spite of the rabbi exposing him to a sceptical argument about the issue at hand.

\section{The Kuzari V, 14}

The passage near the end of $\mathrm{V}, 14$, the focus of my discussion now, ${ }^{105}$ is one of the most important passages of The Kuzari in terms of understanding the fideist trend that characterises Halevi's thought throughout this work, a general feature that I

105 V, 14 (328, ll. 5-26 = Bashir, 538-39). 
discussed in the previous chapter of this study. The passage is unique in that it provides excellent support for the fact that despite the significant changes Halevi made to these sceptical motifs, their origins in the world of ancient Hellenistic philosophy are more explicit here than in any other part in The Kuzari.

At the beginning of the passage under discussion, Halevi briefly restates one of the conspicuous assertions of his thought, according to which our world - as God created and organised it - contains an unchangeable and unbridgeable essential ontological difference between humans who are "flesh and blood" (al-bašar) and those who are of a level called "the choicest of creation" (șafwat al-halq). In addition to their normal human nature, the chosen ones were also given a supra-human nature. This supra-human nature is what allows the existence of a special channel of communication between God and the chosen. The historical revelations of this special channel of communication exclusively occurred in the sphere of the history of the chosen group - the people of Israel - and in the sphere of unique individuals ( $a f r \bar{a} d)$ in the era that preceded the appearance of the people of Israel. The revelations from this channel apply to the individuals receiving this divine inspiration, first and foremost the prophets. These individuals arose from the ranks of the people of Israel, a nation whose individuals were all granted a supra-human nature in potentia. Halevi presents this assertion in detail at different points earlier in The Kuzari, especially in its first and second parts. Here, in a passage from the last part of the work, he repeats it in a concise, instructive manner:

Surely, you have let yourself be deceived by corrupt imaginings and sought what your Creator did not make it possible for you [to grasp]. Neither was the ability to apprehend it by reasoning put within the natural disposition of flesh-and-blood (garizat al-bašar). However, that [kind of ability] was put within the natural disposition of those who are chosen from among the choicest of creation (garizzat al-muștafin min șafwat al-halq) in keeping with the conditions we have mentioned. They come to have those very \{souls\} that conceive of the world in its entirety. They see their Lord and His angels. They see one another, and they know one another's innermost thoughts, just as it says, $I$ know it, too; be silent (2 Kings 2:3, 5). [V, $14(328,11.5-11=$ Bashir, 538)]

In another study, I dealt extensively with the hierarchical-ontological claim to which Halevi briefly returns here. ${ }^{106}$ For the current study, this claim is relevant in that it serves as an introduction and foundation for presenting the central fideist distinction in Halevi's thought: the distinction between divine wisdom and human wisdom to which I alluded earlier. Focusing the discussion on this part of the rabbi's statement in V, 14 allows me to add a clarification on this topic. Halevi's fideism contains the unusual assertion that prophecy and divine inspiration are not fundamentally human phenomena. The prophets and the divinely inspired were those who were granted a supra-human nature from birth that is distinct to the chosen

106 Krinis, God's Chosen People (especially 137-39, 169-70, 175-76, 295-96). 
group (al-șafwah) and therefore, they cannot help but emerge from the ranks of this group. Accordingly, the rabbi, directly continuing his earlier speech on the hierarchical-ontological distinction between the chosen and the non-chosen, takes pains to stress the ontologically lower status of the philosophers (identified with the Hellenistic ethnic group) as ones who share "the natural disposition of flesh-andblood" (garizat al-bašar) compared to the elevated "natural disposition of those who are chosen from among the choicest of creation" (garizat al-muștafin min safwat al-halq), such as the prophets:

We do not understand how that happens or by what means, except that it comes to us by way of prophecy. If the philosophers' knowledge regarding that was true, they would surely have attained it themselves, since they talk about souls and prophecy [a great deal], but they are like the rest of flesh-and-blood ( $k a$-să'ir al-bašar). To be sure, they have excelled in human wisdom (bi-l-hikmah al-insāniyyah), as Socrates used to say to the people of Athens, "O people! I do not deny your divine wisdom (hikmatakum al-ilāhiyyah); rather, I say that I am not conversant with it (lastu ahsunuhā). On the other hand, I am wise with regard to human wisdom (bihikmah insāniyyah)." Actually, they should be excused because they took refuge in their reasoning due to the absence of prophecy and the divine light among them (li-'adam al-nubuwwah wa-l-nūr al-ilāhī 'indahum). Even so, they brought the demonstrative sciences (al-'ulūm alburhāniyyah) to a [level of] perfection that cannot be surpassed, and in that respect they were unique. There is no difference [of opinion] between any two individuals concerning those sciences; but there is almost no agreement between any two individuals about what they undertook [to explain] beyond that with respect to [their divergent] opinions concerning metaphysics (mā ba'd al-tabí'ah) and, yes, concerning many things in physics (al-țabī'a) as well. [V, 14 (328, 11. 11-21 = Bashir, 538-39)]

The transition from the introduction that Halevi places in the rabbi's mouth, based on the above-described hierarchical-ontological claim, to what follows in this passage is a transition from a claim that has absolutely nothing to do with a sceptical discourse to several further claims in which the classical sceptical discourse plays a central role. ${ }^{107}$

In terms of its sceptical background, in these lines, Halevi once again interweaves the argument about the lack of agreement among the philosophers. We have already seen him making this point in the opening dialogue between the rabbi and the Khazar king in I, 13. According to this classical sceptical claim of "dispute"

107 The two parts of this passage do not fit together convincingly. If, as emphasised in the first part of it, "divine wisdom" is restricted to those with the "natural disposition of those who are chosen from among the choicest of creation," how can it be ascribed to a non-chosen group such as the "people of Athens": the addressees of Socrates's speech here? One may agree with Leo Strauss that "Halevi noticed Socrates' irony" and that saying "that he does not grasp the divine wisdom of the people to whom he is talking [...] is evidently a polite expression of his rejection of that wisdom.” Yet when it comes to divine wisdom as Halevi perceives it - i.e., as a revelatory knowledge bestowed upon the chosen group - Halevi himself is far from being ironic. See Leo Strauss, Persecution and the Art of Writing, 2nd ed. (Chicago: University of Chicago Press, 1988), 107 n. 23. 
or "disagreement" (diaphônia), the philosophers' lack of agreement is a clear sign of their lack of knowledge: the absence of an agreement among those debating a certain issue reflects their inability to reach true knowledge of that issue. ${ }^{108}$ In I, 13 , the rabbi applies this claim to the philosophers who cannot agree "on a single action or a single belief" of a "syllogistic, governmental religion." Moreover, in V, 14, the rabbi applies it to metaphysics ( $m \bar{a} b a^{\prime} d a l-t a b \bar{l}^{\prime} a h$ ) as a scientific discipline in which "there is almost no agreement between any two individuals" (i.e., philosophers). Immediately afterwards, he also applies the claim of the lack of agreement among philosophers, though in a more reserved manner, to the discipline of physics (al-tabi' $a h)$. Although he relies heavily on the sceptical claim of the philosophers' lack of agreement, the rabbi's manoeuver here does not reflect the global sceptical approach typical of the Academic and Pyrrhonian sceptics of antiquity. Beforehand, the rabbi invokes a non-sceptical claim that in "the demonstrative sciences" (al'ulūm al-burhāniyya) - that is, the disciplines the rabbi identifies with mathematics and logic (al-riya didiyya wa-l-mantiq) at the start of $\mathrm{V}, 14^{109}$ - there actually is agreement among the philosophers and scientists engaged in them ("There is no difference [of opinion] between any two individuals concerning those sciences”).

In this context, it is highly instructive to compare these statements with some statements made by the famous Hellenistic scientist Claudius Ptolemy in the introduction to the most important Hellenistic scientific treatise on astronomy, the Almagest:

From all this we concluded, that the first two divisions of theoretical philosophy should rather be called guesswork than knowledge, theology because of its completely invisible and ungraspable nature, physics because of the unstable and unclear nature of matter; hence there is no hope that philosophers will ever be agreed about them; and that only mathematics can provide sure and unshakeable knowledge to its devotees, provided one approaches it rigorously. ${ }^{110}$

In its broad strokes, Halevi's claim parallels that of Ptolemy. It is not inconceivable that he relied on the Almagest outright, either directly or indirectly through some mediating text. ${ }^{111}$ In fact, it is highly likely that Halevi knew Ptolemy's ideas and

108 Barnes, The Toils of Scepticism, 6.

109 V, 14 (322, ll. 22-25 = Bashir, 533-34).

110 Ptolemy, Ptolemy's Almagest, trans. Gerald. J. Toomer (New York: Springer, 1984), 36.

111 Consider the rabbi's immediate response to the Khazar king's praise of the philosophers in V, 13 (322, 11. 22-25 = Bashir, 533-34): "This is exactly what I was afraid of concerning you - that you would let yourself be deceived and calmly accede to their opinions. After their demonstrations in the mathematical sciences and logic turned out to be sound, according to them, people willingly accepted everything they said about physics and metaphysics.” This response at the very beginning of V, 14 is in the spirit of al-Ġazālì’s critique of metaphysics. However, al-Ġazālī, unlike Halevi, treated physics as a largely valid science. See al-Ghazālī, Deliverance from Error, 65-66 (sec. 4546); al-Ghazālī, The Incoherence of the Philosophers, 4. See also Griffel, "Taqlīd of the Philosophers," 288-89, 290 n. 55. 
used them, because the Almagest was one of the best-known and most common ancient texts in Arabic culture. ${ }^{112}$ In the statements he voices through the rabbi in V, 14, Halevi follows the selective scepticism that Ptolemy articulated in the introduction to the Almagest. According to both authors, the lack of agreement among philosophers in matters of a field of cognition as ungraspable as metaphysics (the parallel to theology in Ptolemy) and in a somewhat clearer, though still difficult to grasp field such as physics is proof that these fields lie beyond the scope of human intellectual perception, whereas the mathematical fields lie within the grasp of the human mind. The main difference between the two authors is that for Ptolemy, this selective sceptical approach serves as a justification for focusing his scientific work on mathematics, which "can provide sure and unshakeable knowledge to its devotees.” By contrast, for Halevi, the selective sceptical approach serves a very different purpose; namely, a fideist purpose that stresses that the superior knowledge that the philosophers include in the disciplines of metaphysics and physics falls outside of their intellectual scope "due to the absence of prophecy and the divine light among them" (li-'adam al-nubuwwah wa-l-nūr al-ilāhī 'indahum). This knowledge falls within the scope of the "divine wisdom" attained by God's chosen, who merited prophecy and the divine light. Thus, according to Halevi, the knowledge that belongs to this realm of wisdom is not unavailable to mankind, as one might think when reading Ptolemy's thoughts on the matter. Mankind reaches this type of knowledge through the mediation of those prophets whose knowledge is a divinely inspired, non-intellectual knowledge. Elsewhere in The Kuzari, Halevi stresses this lesson, which, in his fideist approach, requires that one abandon "doubtful natural science" ('ilm țabī'i maškūk) $)^{113}$ by means of an anecdote that he attributes to Plato: ${ }^{114}$

Now Plato had already spoken [in this connection] about the prophet who lived at the time of King Marinus [reporting] that he told the philosopher who let himself be deceived by false hope about philosophy [the following] by means of a revelation from God: "You will not reach Me in this way, but only through those whom I have made intermediary between Myself and My creatures," meaning, the prophets and the true nomos [IV, 27 (282, 1. 28-284, 1. 3 = Bashir, 499)]

To the incisive claim he makes in V, 14 about the lack of agreement among philosophers in metaphysics and physics, the rabbi immediately adds a second claim explaining the formation of philosophical schools of thought, a phenomenon whose

112 On the reception of the Almagest in Arabic culture, see Paul Kunitzsch, "Almagest: Its Reception and Transmission in the Islamic World," in Encyclopaedia of the History of Science, Technology, and Medicine in Non-Western Cultures, ed. Helaine Seler, 2nd ed. (Dordrecht: Springer, 2008): 1:140-41. 113 IV, 27 (282, 11. 27-28 = Bashir, 499).

114 See Pines, "Shī'ite Terms and Conceptions," 236-39, for a parallel of this anecdote in the Pseudo-Platonic Kitāb al-nawāmīs. 
existence would seem to require at least a measure of agreement among some of them:

Even if you did find a group [of philosophers] agreeing on a single opinion, that is not due to an investigation [they conducted] and a conclusion at which their [collective] opinion arrived. On the contrary, the fact is that they are followers of one of the dialecticians (al-mutakallimin) who engaged in such discussions, whom they follow in the way of imitation (yuqallidūnahu), like the followers of Pythagoras, the followers of Empedocles, the followers of Aristotle, the followers of Plato, and others, as well as the Stoics (așhāa al-mizallah), and the Peripatetics (almašš $\bar{a}$ '̄n), namely, those who belong to the followers of Aristotle. [V, 14 (326, 11. 21-26 = Bashir, 539)]

Earlier in the dialogue of The Kuzari, in the conclusion to the long section IV, 25, Halevi had already had the rabbi say something similar, though more concise. The rabbi's previous statement points to the same explanation of the transition from a lack of agreement among the philosophers to the emergence of schools of philosophical thought:

Beyond that, there is no agreement between any two of them, except for the imitators who subordinated themselves (al-muqallidūn aladina yuqallidūn) to a single master, whether that be Empedocles, or Pythagoras, or Aristotle, or Plato, as well as numerous others besides them. Not one of them [fully] agrees with his fellow. [IV, 25 (282, 1l. 11-14 = Bashir, 498)]

The way in which Halevi uses conjugations of the Arabic root q.l.d. in the second verbal form in these two segments to mean "imitation," "conformism," or "subordinating oneself to the opinion of" is reminiscent of a claim al-Ġazāli directs at contemporaneous adherents of philosophy in several places in his writings where he asserts that the successful apodictic foundation of the mathematical sciences on logical proofs has made such an impression on these adherents that it causes them to adopt the philosophers' opinions on metaphysics as well. However, they do this not through independent, unbiased intellectual inquiry, as rationalism would demand, but rather through taqlid: blind reliance lacking examination or study. ${ }^{115}$ This corrupt path taken by the adherents of philosophy prevents them from realising that when it comes to metaphysics, the knowledge that the philosophers purport to have lacks any of the demonstrative, apodictic foundations that they achieved in the mathematical sciences. ${ }^{116}$ Al-Gazālī's assertion here and the assertion that Halevi formulates in IV, 25 and V, 14 are similar both in terms of content and in their

115 For the background to Al-Ghazālī's approach to taqlïd in Ash'arite theology, see Richard M. Frank, "Al-Ghazāli on Taqlìd: Scholars, Theologians and Philosophers," Zeitschrift für Geschichte der Arabisch-Islamischen Wissenschaften 7 (1991/92): 246 n. 76; Frank, "Knowledge and Taqlìd," 44 n. 19.

116 Al-Ghazālī, Deliverance from Error, 63-64 (sec. 38-39); Al-Ghazālī, The Incoherence of the Philosophers, 2-3, 8. 
use of terminology based on the root q.l.d. At the same time, there is a striking difference between the two thinkers: Halevi uses the root q.l.d. to explain the emergence of ancient Hellenistic philosophical schools of thought, whereas al-Ġazāli uses it to explain why some of his contemporaries follow the philosophers' conclusions in the realm of metaphysics in general, without reference to divisions into schools. ${ }^{117}$ Thus, al-Ġazālī's statements on taqlīd in the philosophical context lack the stress that is so central to the use Halevi makes of the word's root in the same context, the stress regarding the connection between the philosophers' disagreements and their groupings into schools of thought. ${ }^{118}$

In addition to the connection between the rabbi's words in the parallel segments of IV, 25 and V, 14 and the assertions of al-Ġazālì, it is necessary to note the connection between the rabbi's claims and the claims made by Cicero in his introduction to Lucullus, his major Academic sceptical dialogue. In a passage of this introduction, Cicero notes the advantages of the sceptics compared to the followers of the dogmatic philosophical methods. According to him, the sceptics are freer in their opinions than the dogmatics, because the sceptics, as people who always rely on their independent considerations, are exempt from the burden of obligation borne by the dogmatics to defend a set of positions imposed on them by someone else, that someone else being the founder or teacher of the school of thought to which they belong. Later on, Cicero provides a somewhat sociological explanation of the circumstances in which the dogmatic schools of thought came into being: at the outset of their intellectual path, people tend to be influenced by the doctrine and authority of the particular scholar that they happen to encounter first. From that stage onwards, they simply continue to subordinate themselves to that particular scholar and doctrine, without independently investigating any other opinions or positions. ${ }^{119}$ With these claims, reflecting a sceptical, anti-dogmatic point of view, Cicero provides a polemical explanation for the existence of different philosophical schools that is quite similar to Halevi's polemical explanation embedded in the rabbi's statement on the matter. Both authors criticise the philosophers and their supporters for having aligned themselves with one school or another not as the result of a process of intellectual inquiry on their part, but simply as the result of their inclination to subordinate their own opinions to the authority of a figure representing one of these schools. Using this polemical explanation, Cicero seeks to highlight the advantage of the sceptical path. He describes the sceptics' conduct as consistent and rationalistic, which, unlike that of the dogmatists, does not negate the spirit of independent inquiry in the face of an obligation to the principles of the doctrine of a teacher or the founder of a school of thought. For Halevi, however, the same type

117 See the discussion below on Halevi's use of the device of historicisation in this context.

118 See Frank, "Al-Ghazālī on Taqlīd," 244-50; Griffel, "Taqlìd of the Philosophers."

119 Cicero, On Academic Scepticism, 6-7 (Lucullus, sec. 8-9). 
of polemical explanation is meant to clarify that the groupings and agreements among philosophers and their supporters around consensual positions in physics and metaphysics do not constitute a counter-argument to the claim of the lack of agreement among philosophers that he noted earlier. Subsequently, it cannot provide authentication for the philosophers' claims in these fields. Their groupings do not constitute a full agreement of the kind found among the prophets, according to Halevi; ${ }^{120}$ they are merely factional groupings around schools of thought. Furthermore, these groupings are, rationalistically speaking, the result of an invalid act of subordination to the authority of a teacher or the founder of a school lacking the basic rationalistic condition of independent thought or consideration. With this rationalistic claim, the criticism that Halevi levels against the philosophical schools of thought overlaps with the rationalistic claim that Cicero, the spokesman of scepticism, levels against them.

The third component of the passage of the rabbi's words in V, 14 under discussion that relates to Hellenistic scepticism is how the character of Socrates is introduced. The words attributed to Socrates - which also appear, with slight variations, in IV, 13 - are a paraphrase of a passage from Plato's Apology $(20 \mathrm{~d}-\mathrm{e}) .{ }^{121}$ In both places, Socrates's words support the fideist stance that Halevi's rabbi takes; namely, the stance according to which the most elevated fields of knowledge considered divine wisdom (al-'ilm al-ilāhi) lie outside the scope of cognition of the philosophers, who, when addressing these fields, rely on "the way of reason" (țariq al-qiyās). ${ }^{122}$ The fideist component is stressed here by how Socrates distinguishes himself from

120 Concerning the prophets, see V, 14 (328, 11. 10-11 = Bashir, 538): "They see their Lord and His angels. They see one another, and they know one another's innermost thoughts, just as it says, $I$ know it, too; be silent (2 Kings 2:3, 5)"; IV, 3 (238, 11. 22-26 = Bashir, 447): “Thus, it [i.e., the prophets' "inner eye" - E.K.] sees great and awesome forms, which point to realities about which there is no doubt; and the greatest proof for their reality is the agreement of that entire class, I mean, all of the prophets, about those forms. For in fact, they witness things that mutually attest to one another, just as we do with regard to the things we perceive with our [external] senses."

121 There are considerable similarities between the paraphrasing of Socrates's statement in al-Fārābī's Book of Demonstration (Kitāb al-burhān) and Halevi's two variations on it (especially the one in V, 14). Those similarities make it likely that al-Fārābī’s paraphrase, or a source used by al-Fārābī, served as the source for Halevi's paraphrases. See the discussion in Yehuda Halper, "Socrates and Socratic Philosophy in Judah Halevi’s Kuzari,” Jewish Quarterly Review 107, no. 4 (2017): 466-68. 122 IV, 13 (254, 11. 4-9 = Bashir, 464-65): "However, even though [the philosophers] have gone this far [from the truth], they may nonetheless be excused because they were not in a position [to grasp] divine science except by way of reason, and this is what their reasoning has brought them to. Those among them who are fair-minded say to those who follow a revealed Law what Socrates said: ' $O$ people, I do not deny this divine wisdom of yours. Rather, I say that I don't comprehend it. I am wise only in human wisdom.” 
the rest of the people of Athens as someone who remains within the scope of human wisdom without pretensions to the divine wisdom that they supposedly possess. ${ }^{123}$ The Socrates of V, 14 differs from the other philosophers mentioned in the passage by not having founded or belonged to any school of thought. The fact that Socrates did not found a school is consistent with the humble, limited philosophical approach to which he was committed, according to the words attributed to him. Socrates, as someone who did not claim to have divine wisdom, avoided the path of the other Greek philosophers listed (Pythagoras, Empedocles, Aristotle, Plato, and the Stoics) who attempted to formulate systematic, orderly philosophies that included the higher fields of science; namely, physics and metaphysics. The impression created by the rabbi's statements in V, 14 is that Socrates, in his humble philosophical approach, kept his thought from becoming an authoritative pole of attraction for adherents and followers through whom he would have become the founder of a school. This would seem to indicate that Socrates is exempt from the charge aimed at the founders of the philosophical schools whose adherents follow them through imitation and self-subordination to their founders' authority instead of making their own way through independent thought. ${ }^{124}$

In the context of the Arabic culture in which Halevi lived and worked, his emphasis on the uniqueness of Socrates who, as a Greek philosopher, nonetheless steered clear of divine wisdom and did not found a school of thought, is quite striking and differs markedly from the common characterisation of Socrates as a philosopher in the Arabic literature of that era. ${ }^{125}$ For example, al-Ġazālī included Socrates, along with Plato and Aristotle, among the philosophers whom he called the alilāhìun, those philosophers who devoted a central part of their thought to the field of al-ilāhìat, metaphysics, ${ }^{126}$ and he also counts Socrates among those philosophers who founded schools of thought. ${ }^{127}$ Halevi himself was aware that the rabbi's description of Socrates differed from the way he was usually seen in the rationalist philosophical discourse of his time. This is evident from the words he has the philosophers' representative speak in the first section of The Kuzari. This represen-

123 The emphasis on Socrates's dissociation from divine wisdom is more pronounced in the variation in IV, 13. In this variation, where the addressees are "those who follow a revealed Law" ( $m u$ tašarri ‘iyn), he professes: "I don’t comprehend” divine wisdom (lastu ahșiruhā). In the variation in $\mathrm{V}, 14$, where the addressees are "the people of Athens" (ahl atiniya $)$, Socrates is more reserved in his assessment regarding his connection to divine wisdom, explaining that he is "not conversant with it” (lastu ahsunuhā).

124 Gabriel Danzig, "Socrates in Hellenistic and Medieval Jewish Literature, with Special Regard to Yehuda Hallevi's Kuzari," in Socrates from Antiquity to the Enlightenment, ed. Michael Trapp (Aldershot: Ashgate, 2007): 156.

125 Ilai Alon, Socrates in Medieval Arabic Literature (Leiden: Brill; Jerusalem: Magnes Press, 1991), 93-98, 103-11.

126 Al-Ghazālī, The Incoherence of the Philosophers, 2.

127 Al-Ghazālī, Deliverance from Error, 62-63 (sec. 33-34). 
tative does not hesitate to include Socrates in the group of well-known Greek philosophers to whom he attributes a perfection that elevates them to the metaphysical level of the active intellect. ${ }^{128}$

An examination of the distance between the presentation of Socrates in Arabic philosophical literature and the description of him in the rabbi's words in V, 14 reveals a similarity to the understanding of the figure of Socrates in the Hellenistic school of Academic scepticism. Socrates was revered in the tradition of Academic sceptical thought. He was respected not as a sceptic, ${ }^{129}$ but rather as an anti-dogmatic philosopher, in the sense of one who avoided presenting a systematic philosophical doctrine, opting instead to remain true to dialectical philosophising, avoiding determinations and ultimate conclusions on the issue under discussion. ${ }^{130}$ In the tradition of Academic scepticism - and other traditions as well - Socrates was seen as a model philosopher for focusing on everyday ethical matters rather than on vague theoretical issues that were divorced from human cognition and inaccessible to the human mind, such as the nature of the supreme beings and other matters outside the scope of physics. Socrates thus distinguished himself from other philosophers who tended to preoccupy themselves with such questions. ${ }^{131}$ The congruence between the way in which Socrates was held up as a model of a non-dogmatic philosopher in the Academic sceptical tradition and the way in which he is presented as such a model in the rabbi's words in V, 14 may not be absolute, but it is quite significant nonetheless. This partial but important congruence is especially striking given what I noted above regarding the very different image of Socrates fashioned in the Arabic literature of Halevi's era.

To conclude the discussion, it bears noting that in $\mathrm{V}, 14$, Halevi uses one of his favourite literary devices, that of historicisation. ${ }^{132}$ In the dialogical context, V, 14 is a polemic against dogmatic philosophical doctrine and its stance on the human soul and its purpose in life, a topic on which the rabbi expounds in V, 12. This doctrine belongs to none other than Abū 'Alī ibn Sīnā (d. 1037), and the words in V, 12 are nothing but a paraphrase of many of Ibn Sīnā's statements on the topic in his

128 I, 1 (6, 1l. 5-9 = Bashir, 156). See Danzig, "Socrates in Hellenistic and Medieval Jewish Literature," 153; Halper, "Socrates and Socratic Philosophy," 448.

129 Cicero, On Academic Scepticism, 106 (Academici Libri, sec. 45).

130 Cicero, On Academic Scepticism, 72 and n. 191 (Lucullus, sec. 123), 92-93 (Academici Libri, sec. 16-17); Cicero, On the Nature of the Gods, 12-14 (I, 5). See Burnyeat, "Antipater and Self-Refutation," 293-99; Halper, “Socrates and Socratic Philosophy,” 466.

131 Cicero, On Academic Scepticism, 92 (Academici Libri, sec. 15). See Anthony A. Long, "Socrates in Later Greek Philosophy," in The Cambridge Companion to Socrates, ed. Donald R. Morrison (Cambridge: Cambridge University Press, 2011): 358-60.

132 As already noted, the most conspicuous use of this device is the setting of the work's general plot in the eighth-century kingdom of Khazaria. 
Compendium on the Soul (al-Maqālah fi al-nafs). ${ }^{133}$ The intense polemical note in the rabbi's words against the philosophers in V, 14 - "they talk about souls and prophecy [a great deal], but they are like the rest of flesh-and-blood"134 - is chiefly aimed at Ibn Sinnā, whose doctrines on these matters Halevi had the rabbi voice in V, 12, without attribution. The fact that immediately afterwards, in V, 14, Halevi speaks of Socrates and the Greek philosophers and their schools of thought in antiquity, who belonged to an era that had long since passed, is a clear example of historicisation, which serves as an important literary device in Halevi's discreet relation to his immediate circle of readers (which was more or less identical with his social circle). Here, Halevi means to provide those readers with an obvious hint concerning the balance of power between the adherents of dogmatic rationalism and their opponents: at the time when philosophy was flourishing in ancient Hellenistic culture, this type of dogmatism set the tone for and gave rise to many schools of thought, whereas its opponents, such as Socrates, were few and were considered atypical. Similarly, at the time when Halevi wrote The Kuzari, when rationalistic theology and philosophy were flourishing in Arabic culture, the dogmatic rationalist approach had the upper hand, whereas its opponents were few and were considered outliers. ${ }^{135}$ As we shall see in our next chapter in this study, when it comes to the Judeo-Arabic culture of his era, Halevi played the role of a one-man opposition to the dominant dogmatic rationalist approach.

133 On this early work by Ibn Sīnā, see Dimitri Gutas, Avicenna and the Aristotelian Tradition: Introduction to Reading Avicenna's Philosophical Works (Leiden: Brill, 1988), 82, 171.

134 V, 14 (328, ll. 12-13 = Bashir, 538).

135 See Danzig, “Socrates in Hellenistic and Medieval Jewish Literature,” 152. 
